\section{SEJARAH MUSIK KERONCONG DI SURABAYA}

Rully Aprilia Zandra

PPs ISI Yogyakarta

email : rullyzandra@icloud.com

\section{Abstrak}

Penelitian ini bertujuan mendeskripsikan sejarah musik keroncong di Surabaya. Metode penelitian ini adalah deskriptif kualitatif dengan pendekatan studi kasus.Teknik pengumpulan data dilakukan dengan (1) pengamatan, (2) wawancara, dan (3) dokumentasi. Sumber data yang digunakan berasal dari (1) narasumber/informan, (2) data tertulis, (3) foto, dan (4) rekaman musik. Hasil penelitian menunjukkan bahwa keroncong telah ada di Surabaya sejak awal abad ke-19 dan berkembang hingga sekarang. Perkembangannya sangat dinamis sehingga menghasilkan musik keroncong yang memiliki karakteristik khas. Sejak abad ke-20 perkembangan musik keroncong di Surabaya dipengaruhi oleh pasang surut suasana politik. Pengaruh politik terhadap musik keroncong terlihat pada bentuk dan gaya penyajiannya.

\section{Kata kunci: keroncong, keroncong gaya Surabaya, Markasan}

\section{THE HISTORY OF KERONCONG MUSIC IN SURABAYA}

\section{Abstract}

Keroncong is a genre of music that evolves and lives in Indonesia. Many versions about the origin of keroncong have been raised. There is a version stating that keroncong music was originated from Portuguese, while others state that keroncong is an Indonesian local genius. It is quite possible that Surabaya as one of the cities in Indonesia with its dinamic political development has influences to its musical history, form, and presentation style. Based on this background, the question research is how the history of keroncong music in Surabaya is. The method used in this research was qualitative, and case study approach. The data collection techniques were: (1) observation, (2) interview, and (3) documentation. The data sources used were obtained from: (1) informants, (2) printed documents, (3) photos, and (4) music audiorecordings. The validity of the data was tested by triangulation data. The triangulation used in this study were time triangulation, source triangulation, and method triangulation. The analisis technique was domain analysis. The results show that Keroncong has existed in Surabaya since the beginning of the 19th century to the present with a dynamic development, so it produces keroncong music that has special characteristics. Since the 20th century the development of keroncong music in Surabaya has been influenced by tidal political atmosphere.

Keywords: Keroncong, Surabaya Keroncong Style, Markasan

\section{PENDAHULUAN}

Keroncong merupakan salah satu genre musik yang berkembang dan hidup di Indonesia. Para ahli telah banyak mengemukakan versi mengenai asalusul musik keroncong. Ada versi yang menyatakan bahwa musik keroncong berasal dari Portugis. Ada pula yang berpendapat bahwa keroncong adalah local genius bangsa Indonesia. Selain itu, ada pula pendapat yang menyatakan bahwa keroncong adalah hasil pembauran antara musik Barat (Portugis) dan musik Timur (Indonesia).

Dalam perkembangannya, keroncong telah memiliki berbagai macam gaya permainan. Sebagaimana telah diakui oleh masyarakat Indonesia (terutama masyarakat musik) berbagai macam gaya permainan musik keroncong tersebut yaitu, gaya Lama, gaya Jakarta dan gaya Solo (Desrilland, 2001: 42-47; Any, 1997: 2).

Surabaya, misalnya, memiliki potensi sebagai tempat berkembangnya berbagai jenis musik, termasuk musik keroncong. Masyarakat Surabaya secara umum telah dikenal memiliki identitas budaya yang sangat khas. Hal ini tercermin dalam hal kreativitas berkesenian dan interaksi sosialnya. Berkaitan dengan perkembangan musik keroncong di Indonsia, Surabaya memiliki andil yang perlu diperhitungkan. Secara historis dinamika perkembangan musik keroncong di Indonesia sangat dipengaruhi oleh perkembangan sosial politik (Desrilland, 2001: 1). Terlebih Surabaya sebagai salah satu kota yang memiliki perjalanan perkembangan politik yang sangat panjang dan menyejarah.

Musik keroncong yang berkembang di Surabaya memiliki karakteristik yang sangat khas. Kekhasan itu merupakan cermin budaya masyarakat Surabaya. Secara musikal, musik keroncong yang hidup dan berkembang di Surabaya memiliki gaya permainan yang sangat berbeda bila dibandingkan dengan gaya Lama, gaya Jakarta, maupun gaya Solo. Perbedaan tersebut terletak pada teknik permainan, lirik, maupun gaya permainannya yang sangat khas yang merupakan gaya Surabaya. Akan tetapi, istilah Keroncong gaya Surabaya itu belum diakui masyarakat, meskipun pada kenyataannya ada.

Keunikan dan kekhasan musik keroncong yang berkembang di Surabaya merupakan manifestasi kekayaan budaya atau genius product(Any, 1997: 2) dari local genius nenek moyang bangsa Indonesia. Penelitian tentang musik keroncong ini lebih difokuskan pada musik keroncong di Surabaya, khususnya tentang gaya Surabaya. 
Penelitian tentang musik keroncong di Surabaya pernah dilakukan oleh peneliti terdahulu yaitu Sulistyohadi dalam bentuk skripsi, dengan judul Perkembangan Musik Keroncong Siaran RRI Surabaya Tahun 1960 Hingga Tahun 1999. Hasil penelitian tersebut mengungkapkan bahwa (1) Perkembangan musik keroncong RRI Surabaya sangat pesat dan mampu menarik mina masyarakat luas, terutama generasi muda, karena RRI Surabaya dapat menjangkau seluruh lapisan masyarakat. Perkembangan musik keroncong dari 1960 sampai 1999 semakin matang dan mempunyai mutu yang dapat diperhitungkan; (2) Musik keroncong RRI Surabaya mampu menempatkan diri sebagai musik yang memilik kualitas dan mengandung nilai seni yang tinggi. Oleh karena itu, RRI Surabaya bersedia memberikan kesempatan kepada grup-grup orkes keroncong maupun penyanyi untuk dapat tampil dalam setiap acara yang disiarkan secara khusus; (3) RRI Surabaya berusaha keras untuk melestarikan musik keroncong dengan mengadakan apresiasi musik keroncong, Festival Bintang Radio, dan acara-acara lainnya (Sulistyohadi, 2000: 54-55).

Hanya saja, penelitian tersebut belum mengungkap sisi historis, bentuk penyajian, maupun gaya musikal keroncong di Surabaya. Berdasarkan latar belakang di atas, rumusan masalah tulisan ini adalah bagaimana sejarah musik keroncong di Surabaya?

\section{KAJIANTEORI}

\section{Musik Keroncong}

Musik keroncong berkembang di pulau Jawa pada abad ke-20 dan dipengaruhi oleh musik-musik daerah (tradisional), terutama di Jakarta, Jawa Tengah (Surakarta), Yogyakarta, serta Jawa Timur (Surabaya) (Harmunah, 1978 : 9-10). Perkembangan musik keroncong di luar Jakarta itu sangat dipengaruhi musik-musik tradisional. Di Jawa Tengah, musik keroncong dipengaruhi musik gamelan (Musik Pentatonis).

Perkembangan keroncong di Jawa Timur dimulai dari teater rakya komedi stambul yang mempergunakan lagu-lagu keroncong di panggung pertunjukan. Musik keroncong dijadikan selingan atau untuk mengiringi bagianbagian dari drama. Berdasar latar belakang itulah tipe keroncong ini disebut stambul (Ernst Heins, 1975: 21).Elemen-elemen dasar atau aspek musikal keroncong ini dapat dilihat dari bentuk musik dan repertoirnya.

Musik keroncong mempunyai lima ciri khas (Harmunah, 1978: 17), yaitu bentuk, harmoni, ritme, alat-alat dan pembawaan.

\section{a. Bentuk}

Yang dimaksud bentuk adalah suatu gagasan atau ide yang tampak dalam penyalahgunaan/susunan semua unsur musik dalam sebuah komposisi (melodi, irama, harmoni, dan dinamika). Bentuk dalam sebuah musik keroncong merupakan keistimewaan genre musik ini, sebab aturan bentuknyalah yang menjadi identitas sekaligus pembeda antara jenis lagu keroncong yang satu dengan lainnya. Harmunah (1987: 17) mengungkapkan terdapat beberapa jenis musik keroncong, antara lain: Keroncong Asli, Stambul, Langgam dan Lagu Ekstra.

\section{b. Harmoni}

\section{a. Keroncong Asli}

1) Dalam tangga nada mayor.

2) Ciri-ciri umum harmonisasinya adalah tetap, yaitu membentuk kadens lengkap I - IV - V - I, dan modulasi II - V, dan hampir selalu setelah modulasi kedominan dilanjutkan dengan akord IV.

\section{b. Langgam}

1) Dalam tangga nada mayor dan tangga nada yang diarahkan dari musik daerah.

2) Ciri harmonisasinya hampir sama dengan jenis keroncong asli, yaitu membentuk kadens lengkap I-IV - V - I dan modulasi II - V.

\section{c. Stambul}

1) Dalam tangga nada mayor

2) Ciri harmonisasinya adalah membentuk kadens lengkap I- IV - V - I, untuk introduksi adalah akord I dengan peralihan ke akord IV.

\section{c. Ritme}

Di dalam musik keroncong, jenis alat yang berperan sebagai pengiring dan pemegang ritmis adalah alat-alat musik ukulele, banjo, cello, dan contrabass.

\section{d. Alat-alat}

Alat musik keroncong asli dipakai sebagai ukuran terdiri atas tujuh macam, yaitu biola, seruling, gitar, ukulele, banjo, selo, dan kontrabas. Jadi apabila sudah ada ketujuh macam alat musik keroncong ini, permainan musik keroncong sudah dapat dikatakan lengkap.

\section{e. Pembawaan}

Terdapat tiga jenis pembawaan pada musik keroncong, yaitu pembawaan dari setiap alat, pembawaan vokal, dan pembawaan dari semua alat secara kelompok.

\section{Gaya Keroncong}

Gaya adalah cara; irama dan lagu (dalam bernyanyi dan bermusik); ragam (cara, rupa, bentuk dan sebagainya); cara melakukan; lagak lagu (tingkah 
laku); perangai yang elok (Poerwadarminto, 2003: 354). Gaya atau style dapat pula diartikan pembawaan atau cara penyajian. Dalam hal ini yang dimaksud adalah cara penyajian atau cara memainkan musik keroncong.

Musik keroncong sebagai musik khas Indonesia dikenal masyarakat (khususnya masyarakat musik) memiliki tiga macam gaya dalam pembawaannya, yaitu pembawaan Keroncong Gaya Lama, pembawaan Keroncong Gaya Jakarta, dan pembawaan Keroncong Gaya Surakarta (Solo) (Budiman, 1979: 42). Ketiga gaya tersebut di awal dapat ditabelkan sebagai berikut.

Tabel 1. Perbedaan Gaya Pembawaan Musik Keroncong

\begin{tabular}{|c|c|c|c|}
\hline Pembeda & Gaya Lama & Gaya Jakarta & Gaya Solo \\
\hline Uculele & $\begin{array}{l}\text { Dua buah stem A } \\
\text { dan E, digaruk }\end{array}$ & Stem A, digaruk & 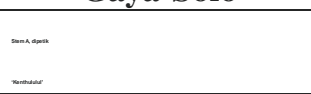 \\
\hline Banjo & 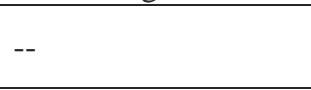 & $\begin{array}{l}\text { Dipetik satu senar } \\
\text { saja }\end{array}$ & $\begin{array}{l}\text { Digaruk akor } \\
\text { lengkap }\end{array}$ \\
\hline Gitar & $\begin{array}{l}\text { Gitar lebih dari satu, } \\
\text { not sinkup dan } \\
\text { treiul, terkadang } \\
\text { ditambahkan } \\
\text { mandolin }\end{array}$ & $\begin{array}{l}\text { Irama grebekan, } \\
\text { tenang lalu tiba-tiga } \\
\text { cepat }\end{array}$ & Tenang \\
\hline Celo & 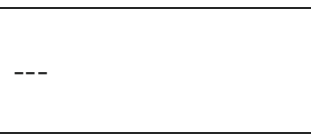 & $\begin{array}{l}\text { Celo lincah, tidak } \\
\text { melankolis }\end{array}$ & $\begin{array}{l}\text { Banyak variasi, } \\
\text { meniru gaya } \\
\text { kendang, melankolis }\end{array}$ \\
\hline Kontrabas & --- & $\begin{array}{l}\text { Dipetik bass dan } \\
\text { kontranya }\end{array}$ & $\begin{array}{l}\text { Tidak hanya bas dan } \\
\text { kontra yang } \\
\text { dibunyikan }\end{array}$ \\
\hline Flute & --- & $\begin{array}{l}\text { Saling isi dengan } \\
\text { biola }\end{array}$ & $\begin{array}{l}\text { Saling isi dengan } \\
\text { biola, tidak } \\
\text { arogan/samar } \\
\text { menjadi background } \\
\text { vokal }\end{array}$ \\
\hline Biola & --- & $\begin{array}{l}\text { Saling isi dengan } \\
\text { flute }\end{array}$ & $\begin{array}{l}\text { Saling isi dengan } \\
\text { flute }\end{array}$ \\
\hline Lirik & $\begin{array}{l}\text { Alam, } \\
\text { kepahlawanan }\end{array}$ & $\begin{array}{l}\text { Alam, } \\
\text { kepahlawanan }\end{array}$ & $\begin{array}{l}\text { Alam, } \\
\text { kepahlawanan }\end{array}$ \\
\hline Harmonisasi & $\begin{array}{l}\text { Tonika, sub } \\
\text { dominan, dominan }\end{array}$ & $\begin{array}{l}\text { Tonika, sub } \\
\text { dominan, dominan }\end{array}$ & $\begin{array}{l}\text { Tonika, sub } \\
\text { dominan, dominan }\end{array}$ \\
\hline
\end{tabular}

\section{Metode Penelitian}

Penelitian ini menggunakan metode kualitatif dengan pendekatan studi kasus. Teknik pengumpulan data dilakukan dengan (1) pengamatan, (2) wawancara, dan (3) dokumentasi. Sumber data yang digunakan berasal dari (1) narasumber/informan, (2) data tertulis, (3) foto, dan (4) rekaman musik. Validitas data diuji dengan menggunakan triangulasi data. Triangulasi yang dipakai dalam penelitian ini adalah triangulasi waktu, triangulasi sumber, dan triangulasi metode. Teknik analisis data yang digunakan adalah analisis domain.

\section{HASILPENELITIAN}

Pada pendahuluan disinggung salah satu pendapat menyatakan bahwa asal-usul musik keroncong adalah dari Portugis yang dibawa para pedagang. Mereka berdagang sampai jauh ke luar negerinya. Ekspansi ekonominya itu kemudian diarahkan ke selatan. Pada 1511 Portugis di bawah pimpinan Alfonso d'Albuquerque merebut Malaka yang pada waktu itu dipimpin Sultan Alauddin Syah. Setelah selama 11 tahun bercokol di Malaka, pada 1522 pedagang-pedagang Portugis itu melanjutkan ekspansinya ke Ternate dan Ambon untuk mencari rempah-rempah, khususnya cengkeh. Dalam perjalanannya menuju ke arah timur itu pedagang/pelaut Portugis singgah di beberapa pulau yang dilaluinya, termasuk Jawa. Sementara pada 1512 Majapahit telah menjalin hubungan dengan bangsa Portugis (Arifin, 1995: 308). Surabaya digunakan sebagai pintu gerbang Majapahit pada masa itu. Hal ini berarti pada 1512 atau awal abad ke-16, secara sosial geografi, Surabaya telah berinteraksi dengan bangsa Barat. Dengan demikian, dapat diduga bahwa embrio musik keroncong telah ada di Surabaya pada waktu itu.

Pada 1800-an di Surabaya telah terdapat lagu yang dinyanyikan dengan irama Kerontjong Liedje. Keroncong Liedje adalah bahasan keroncong pertama yang terdapat pada Surabaia Tempo Doeloe. Surabaia Tempo Doeloe memuat berbagai kejadian monumental beserta segala perubahan dan perkembangan kota Surabaya sejak 1625 (masa pemerintahan Adipati Surabaya pertama, yaitu Pangeran Pekik) hingga Surabaya saat ini (Widodo, 2002: 1-71).

Keroncong Lidje merupakan jenis lagu keroncong yang hanya ada di Surabaya saat itu. Lagu tersebut dibawakan dengan suara yang mendayu-dayu dan liriknya menggambarkan kondisi sosial pada waktu itu. Sebagai contoh adalah syair lagu yang menggambarkan gadis-gadis dari kampung Pesapen dan Krambangan yang saat itu terkenal jelita.

Bukti konkret yang berupa data lagu yang liriknya mengenai kehidupan sosial di Surabaya pada masa itu menjadi salah satu data yang dapat menunjukkan bahwa pada waktu itu komunitas musik keroncong sudah terbentuk di Surabaya. Irama mendayu-dayu dan sederhana merupakan salah satu ciri keroncong gaya lama. Dengan demikian dapat diasumsikan bahwa, pada masa itu kemungkinan memang belum terdapat keroncong Gaya Jakarta maupun Gaya Surakarta. Di samping itu, Langgam maupun Stambul juga belum lahir pada masa itu. Musik 
keroncong Gaya Lama inilah yang nantinya berkembang sesuai dengan ekosistem tempat perkembangannya, meski tidak menutup kemungkinan bahwa gaya-gaya yang dominan di lain tempat juga mempengaruhi perkembangan parsial keroncong di Surabaya.

Sejak masa perkenalan keroncong masuk dalam masyarakat pribumi, telah terjadi banyak penyesuaian yang terjadi, baik dari sisi bentuk musik maupun alatnya. Hal ini disebabkan faktor kebiasaan mendengarkan musik yang nuansa maupun intervalnya berbeda sama sekali, maupun keterbatasan penggunaan alat secara regular. Perkembangan musik keroncong di luar Jakarta sangat terpengaruh oleh musik-musik tradisional. Di Jawa Tengah musik keroncong dipengaruhi oleh musik gamelan (Musik Pentatonis).

Sementara itu, ada pendapat yang menyatakan bahwa di Jawa Timur perkembangan keroncong dimulai dari adanya teater rakyat komedi stambul yang menggunakan lagu-lagu keroncong di panggung sebagai pertunjukan-pertunjukan selingan maupun untuk mengiringi bagian-bagian dari drama. Dari situlah timbul tipe keroncong yang disebut stambul (Heins dalam Harmunah, 1987: 10). Jika mencermati pendapat bahwa stambul adalah kesenian yang berasal atau memiliki perkembangan dominan di Surabaya maka dapat dikatakan musik keroncong jenis stambul kemungkinan merupakan salah satu produk musisi keroncong di Surabaya, yang sudah jelas memiliki karakteristik dan aturan bentuk yang berbeda dengan jenis keroncong lainnya.

Di Malaysia juga terdapat musik keroncong yang digunakan dalam cerita dan ekstra turn (selingan) bangsawan, terutama dalam cerita klasik (Barat) atau cerita Jawa yang masuk pada abad ke-16 dan ke-17 (Matusky\& Beng, 1997: 343). Hal ini dibuktikan pula dengan dimuatnya berita-berita dalam surat kabar pada saat itu mengenai musik keroncong yang diperkenalkan oleh kumpulan-kumpulan teater toneel dari Indonesia.

Jika musik keroncong jenis Stambul berasal dari Istambul, maka Malaysia yang terletak di Malaka sebagai pintu gerbang masuknya budaya Barat dan Timur Tengah sebelum masuk ke pulau Jawa akan mendapat persebaran musik pengiring toneel ini lebih dulu dari masyarakat Jawa. Akan tetapi, jika memperhatikan kenyataan bahwa masyarakat Malaysia mengenal keroncong, khususnya jenis Stambul, dari kumpulan teater toneel Indonesia yang membawakan cerita-cerita Jawa, terdapat kemungkinan teater Stambul bukan berasal dari Istambul, atau bahkan keroncong jenis Stambul adalah genius product 'buaya keroncong' di Jawa Apabila dihubungkan lagi dengan pernyataan Ernst Heins yang menyatakan Stambul berasal dari Jawa Timur, maka Surabaya sebagai pusat perkembangan sosial, politik, dan budaya Jawa Timur mempunyai peluang besar mengklaim keroncong jenis Stambul sebagai salah satu produk budayanya.
Perkembangan musik keroncong di Surabaya pada masa sebelum abad ke20 sulit untuk dikenali dengan lengkap. Untuk melacak perkembangan atau pembentukan gaya keroncong di Surabaya, peneliti melacak perkembangan keroncong di daerah lain, yang pada waktu itu umumnya kelompok pemain musik ini hanya terdiri dari dua atau lebih ukulele, rebana, dan ada pula yang sudah dilengkapi mandolin. Bentuk seperti ini bertahan kira-kira sampai akhir abad ke-

19. Inilah bentuk awal bezzeting keroncong di Surabaya. Selama lebih kurang seratus tahun kondisi perkeroncongan tidak ada kemajuan berarti. Awal abad ke-20 mulai muncul beberapa gelintir masyarakat Surabaya yang tampaknya mulai tertarik lagi untuk mengembangkan musik ini, meski pada masa itu keroncong sedang diolok-olokan sebagai musik dekaden (kampungan). Hal ini serupa dengan perkembangan keroncong di Jakarta. Bermunculanlah grup-grup musik, antara lain "Lief Java" yang didirikan oleh Wang Suwardi (tahun 1922), kemudian "Melayang", "Monte Carlo" dan "Doodskopen" (Sulistyohadi, 2000: 28).

Tahun 1933 lahirlah program yang menyiarkan khusus musik keroncong pertama yang bertajuk "Siaran Radio" di RRI Surabaya. Dampak sementara pada saat itu hanya mempopulerkan eksistensi keroncong di Surabaya dan sekitarnya. Hal itu ternyata berpengaruh kepada beberapa gelintir orang untuk membentuk orkes-orkes keroncong di Surabaya. Selain itu juga menumbuhkan semangat bersaing dalam kemampuan dan kreativitas para seniman musik Surabaya hingga tercetus ide-ide revolusioner dan memunculkan ciri khas gaya Surabaya (Sulistyohadi, 2000: 28)

Pada tahun 1935 terciptalah lagu keroncong dengan kata-kata berupa syair dan bukan lagi berlirik pantun, ialah lagu keroncong "Rindu Malam" (Lagu: Soekamto, Syair: St. P. Bustami). Selanjutnya menyusul lagu-lagu dengan syair yang lain ciptaan Gesang, yaitu Keroncong Si Piatu (1938), Bengawan Solo (1940), Saputangan (1941). Kongkurs (lomba) untuk menggairahkan irama keroncong diadakan setiap tahun sekali waktu ada maleman di Solo. Sementara di Surabaya juga diadakan pada waktu ada Jaarmarkt, dan juga di Bandung, pada waktu ada Bandung Jaarbeurs(Suharto, 1996: 48).

Selanjutnya, pada 1942 dengan kekalahan Belanda dari Jepang, berdampak terhadap eksistensi musik keroncong di Surabaya. Eksistensi musik keroncong agak mengalami kemunduran. Pecahnya perang Asia Timur Raya pada 1942 dan kekalahan Belanda pada Jepang, membawa perubahan suasana di Indonesia. Pada zaman pendudukan Jepang segala sesuatu yang berbau Barat dikikis habis. Sejalan dengan itu jika tadinya irama keroncong dianggap kesenian/ musik kelas bawah karena dianggap remeh, maka pada zaman Jepang justru mendapat angin baik. Tahun 1960-an adalah masa pertumbuhan keroncong di Surabaya. Tahun itu merupakan tonggak sejarah yang ditandai dengan diselenggarakannya program siaran musik keroncong di RRI Surabaya. Acara tersebut memacu lahirnya grup-grup orkes keroncong baru di Surabaya. 
Salah satu orkes keroncong yang memiliki popularitas adalah orkes keroncong Aneka Warna yang dipimpin oleh Markasan yang berdiri pada 1960 Orkes Keroncong Aneka Warna ini berhasil memunculkan warna baru dalam perkembangan musik keroncong di Surabaya. Karya monumentalnya adalah lagu 'Keroncong Wajik Abang'. Lagu ini memiliki aransemen yang sangat berbeda dibandingkan dengan lagu-lagu keroncong pada ketiga gaya lainnya, yaitu gaya Lama, gaya Solo, maupun gaya Jakarta. Selain perbedaan aransemen, lirik lagunya pun memiliki keistimewaan, yaitu berisi kritik sosial. Hal ini tidak lazim ditemukan pada gaya keroncong pada masa itu. Bila gaya keroncong lain umumnya menggunakan lirik lagu yang menggambarkan pemujaan terhadap alam, syair pemujaan terhadap pahlawan, tetapi keroncong Aneka Warna lebih menekankan syair yang berisi kritik sosial, terutama kritik terhadap penguasa waktu itu. Gaya ini disebut 'Gaya Markasanan'.

Perkembangan keroncong gaya Markasanan terhenti pada pertengahan 1965 hingga 1967. Sebab, pada pertengahan 1965 di Indonesia terjad pemberontakan G30S/PKI. Penguasa pemerintahan pada waktu itu melarang adanya kegiatan berkumpul, lebih-lebih membentuk organisasi-organisasi sosial.

Pada 1967 kondisi sosial politik di Surabaya sudah mulai stabil. Orkesorkes yang sempat bubar sementara, saat itu muncul lagi membangun kreasikreasinya lagi. Akan tetapi, OK Aneka Warna terbentuk ulang menjadi dua grup. Grup pertama tetap dipimpin Markasan dan memainkan gaya Markasanan saja sebagai ciri OKAneka Warna.

Sementara grup kedua yang berusaha mengurangi bayang-bayang nama besar OK Aneka Warna dengan cara menggabungkan empat konsep gaya yang sedang populer, yaitu gaya Lama, gaya Jakarta, gaya Solo, dan gaya Markasan.

Warna keroncong di Surabaya pada masa itu, sangat dipengaruhi perubahan selera masyarakat, dan pola pikir, maupun kemajuan teknologi, khususnya alat-alat musik elektrik yang mulai marak dikenal di Indonesia. Seiring perkembangan teknologi yang kian maju, banyak perubahan-perubahan yang kadang memancing kontroversi, seperti penggunaan synthesizer, organ, gitar elektrik, maupun bass elektrik; sampai-sampai ada yang menyingkirkan instrumen biola dan flute dalam repertoarnya (Any, 1997: 7). Pembaharuan yang dilakukan Rudi Pirngadi juga berupa pembentukan orkes keroncong dengan formasi orkes symphony dan memasukkan lagu-lagu Barat yang pernah terkenal, diiringi dengan permainan orkes keroncong dalam repertoirnya (Isfanhari, 1997: 9).

Tahun 1971 dalam lomba-lomba orkes keroncong se-Jawa Timur di Surabaya, salah satu peserta mencoba memasukkan paduan suara dalam permainan orkes keroncong. Itulah pertama kalinya orkes keroncong mengiring penyanyi paduan suara. Any (Insfanhari, 1997: 9) pernah memprediksi bahwa sangat mungkin keroncong yang ada saat itu dapat dimunculkan menjadi varietas- varietas baru, seperti keroncong Rock dan keroncong Pop. Pernyataan tersebut dapat diikuti dengan pertimbangan bahwa pada kenyataannya saat ini telah muncul berbagai bentuk penyajian keroncong yang sangat bervariasi, seperti congdut (keroncong dangdut) dan keroncong regae. Dengan demikian perkembangan musik keroncong di Surabaya sejak 1971 hingga sekarang tidak menunjukkan perubahan ciri-ciri yang sangat menonjol.

\section{KESIMPULAN}

1. Perkembangan musik keroncong di Surabaya baru dapat dilacak setelah abad ke-20. Akan tetapi, bukti-bukti lain menunjukkan bahwa sebelum abad ke-20 musik keroncong telah hidup di Surabaya. Pada 1800-an musik keroncong sudah masuk ke Indonesia. Hal ini dibuktikan dengan keberadaan beberapa lagu yang dinyanyikan dengan irama Kerontjong Liedje, yaitu suatu jenis keroncong yang hanya ada di Surabaya saat itu.

2. Setelah abad ke-20 perkembangan keroncong di Surabaya diwarnai oleh pasang surut perkembangan politik, antara lain:

a. Kekalahan Belanda dari Jepang. Hal ini berdampak terhadap eksistensi musik keroncong di Surabaya. Akibat kekalahan Belanda atas Jepang musik keroncong juga mengalami kemunduran.

b. Zaman pendudukan Jepang, musik keroncong justru mendapat angin baik. Jepang justru memberikan penghargaan terhadap kesenian lokal, termasuk musik keroncong.

c. Pada saat terjadi pemberontakan G30S/PKI aktivitas keroncong terhenti selama dua tahun, yaitu pada 1965 hingga 1967. Hal ini dikarenakan pemerintah melarang masyarakat menyelenggarakan perkumpulan dan organisasi.

\section{DAFTAR PUSTAKA}

Any, Andjar 1997. "Musik Keroncong Menjawab Tantangan Zamannya." (Makalah dibacakan pada Penataran Seni Musik oleh Direktorat Kesenian di Cisarua Bogor, 3-12 September)

Arifin,W.P. 1995.Babad Blambangan.Yogyakarta: Ecole Francaise d'ExtremeOrient bekerjasama dengan Yayasan Bentang Budaya.

Budiman, BJ. 1979. Mengenal Keroncong dari Dekat. Jakarta: Tanpa Penerbit. Desrilland. 2001. "Keroncong Musik Khas Indonesia: Sebuah Kajian Musikologis." (Tesis untuk meraih gelar Magister Humaniora, Program Pengkajian Seni Pertunjukan Universitas Gadjah Mada. Jogjakarta: Program Pasca Sarjana Universitas Gadjah Mada).

Widodo, D.I. 2002. Soerabaia Tempo Doeloe. Surabaya: Dinas Pariwisata. 
Heins,Ernst. 1975. Kroncong and Tanjidor - Two cases of urban folk music in Jakarta. Asian Musik VII-I, Journal of the society for Asian Music. Harmunah, 1987. Musik Keroncong (Sejarah, Gaya dan Perkembangan). Jogjakarta: Pusat Musik Liturgi.

Isfanhari, Musafir. 1997. "Musik Keroncong: Komposisi, Permainan dan Sejarahnya." (Makalah dibacakan pada acara Seminar Kesaksian melalui Seni Musik Gerejawi di Malang tanggal 31 Agustus 1997)

Tambunan,Marsha. 2004. Sejarah Musik dalam Ilustrasi. Jakarta: Progres

Matsuki, Patricia \&Beng, Tan Sooi. Muzik Malaysia: Tradisi Klasik, Rakyat dan Sinkretik. Malaysia: The Asian Centre.

Poerwadarminta, W.J.S. 2003. Kamus Umum Bahasa Indonesia. Jakarta: Balai Pustaka

Suharto AH dkk. 1996. Serba-serbi Keroncong, Jakarta: Mustika

Sulistyohadi, 2000. "Perkembangan Musik Keroncong Siaran RRI Surabaya Tahun 1960 hingga Tahun 1999”. (Skripsi untuk meraih gelar Sarjana Pendidikan, Program Pendidikan Seni Drama, Tari, dan Musik Universitas Negeri Surabaya. Surabaya: Universitas Negeri Surabaya)

Tim Penyusun, t.t., Ensiklopedia Indonesia, F-M, N. V. Bandung: Penerbitan W. Van Hoeve, s-Gravenhage

\section{PROSES KREATIF PERUPA I MADE SUPENA}

I Gde Suryawan

Fakultas Bahasa dan Seni Universitas Pendidikan Ganesha Bali email : de_Suryaoneart@yahoo.co.id

\section{Abstrak}

Penelitian ini bertujuan untuk memperoleh gambaran tentang (1) Biografi Supena, (2) Konsep karya Supena, (3) Proses kreatif Supena, (4) Periodisasi karya Supena, dan (5) aspek teks hingga konteks pada karya Supena. Penelitian ini merupakan penelitian kualitatif. Pengumpulan data dilakukan dengan teknik observasi, wawancara, dan telaah dokumen terhadap proses kreatif I Made Supena. Hasil penelitian sebagai berikut. (1) Supena adalah salah satu perupa dari Singapadu, Bali. Ia berasal dari keluarga seniman. Ayahnya, I Ketut Muja, adalah seorang pematung. Kakaknya, I Wayan Jana, juga seorang pematung. Adiknya, I Ketut Sugantika, adalah seorang pelukis. Sementara itu iparnya, Ni Nyoman Sani, merupakan seorang pelukis. (2) Konsep karya Supena adalah menggali persoalan alam dan kehidupan untuk direpresentasikan secara formalistik. (3) Selain melukis Supena juga mengembangkan gagasannya dalam bentuk patung, instalasi, dan Performance Art. Sebagai seorang perupa Supena lebih memilih bekerja secara individual. (4) Priodisasi karya Supena adalah tradisional, formalistik, dan emosi. 5) Karya Supena dapat dibaca berdasarkan pendekatan teks yang menyangkut unsur-unsur seni rupa dan nilai estetis yang terkandung dalam karya, serta dapat pula dibaca konteksnya dengan menarik pemaknaan yang ada dibalik teks karya Supena.

Kata kunci : biografi, konsep, proses kreatif, periodisasi, teks dan konteks

\section{THE CREATIVE PROCESS OF I MADE SUPENO}

\section{Abstract}

This study aimed to obtain the description of (1) the biography, (2) the concept, and (3) the creative process of Supena's works, and also reveal (4) the division of historical periods and (5) the aspects of text and context in his works. This is a qualitative research with the data collection process using observation, interview, and document analysis techniques. The subject of this research is the creative process of I Made Supena. The findings of this study reveal that (1) Supena is one of the artists from Singapadu, and he was born in a family of artists. His father, I Ketut Muja, is a sculptor, while his elder brother, I Wayan Jana, is also a sculptor. His younger brother, I Ketut Sugantika, as well as his sister in law, Ni 
Nyoman Sani, who is the wife of I Ketut Sugantika, is a painter. (2) The concept of Supena's works is to describe about the problems in his nature and the life issues which are then represented in formalistic ways. (3) Besides painting, Supena also develops his ideas in the forms of sclupture, installations and art performance. As an artist Supena prefers working individually meaning that he uses the principle of self-management in the process of his artistic performances and activities. (4) The division of historical periods in Supena's works reveal that his works belong to traditional, formalistic, and emotional groups. (5) The works of Supena are readable through text-based approach that involves the elements of art and aesthetic values embodied in the work itself, and they can also be read by understanding the contextual meanings behind his works.

Keywords: biography, concept, creative process, historicsl periods, text and context

\section{PENDAHULUAN}

Bali memiliki banyak kekayaan seni rupa. Seni rupa Bali tumbuh sangat pesat, baik seni rupa tradisi, modern, maupun kontemporer. Proses regenerasi yang dinamis menjadikan seni rupa Bali tetap eksis dan memiliki pewarisnya masingmasing. Ia tumbuh dalam masyarakat komunal yang mendukungnya. Dalam perkembangannya, banyak desa menjadi pusat pengembangan kegiatan seni rupa, salah satunya adalah Singapadu.

Singapadu, desa di kawasan Sukawati Gianyar Bali, memiliki sejarah panjang dalam dunia kesenian, khususnya seni rupa. Di desa ini terlahir banyak seniman, mulai dari yang otodidak hingga yang menempuh jalur akademik dalam bidang seni rupa. Singapadu juga melahirkan sanggingbarong (pematung tradisional) sekaligus perupa kontemporer. Cokorda Raka Tisnu dan Cokorda Alit, yang lebih dikenal sebagai pematung Muja dan pegiat seni rupa tradisional, merupakan contoh dua orang seniman yang lahir dari desa ini.

Selain dua orang seniman di atas, salah satu perupa kontemporer yang banyak diperbincangkan dalam dunia seni rupa kontemporer Bali adalah I Made Supena. Ia anak dari Muja, seorang pematung asal Singapadu. Tidak seperti sang ayah yang dikenal sebagai pematung, I Made Supena dikenal sebagai pelukis. Namun, dalam karya-karya terbarunya, Supena juga membuat patung sebagai bagian dari karya instalasinya.

Supena memulai kesenimanannya dengan menempuh pendidikan formal seni rupa di Program Studi Seni Rupa dan Desain (PSSRD) UNUD pada 19911997. Ia mulai aktif berkarya dan mengikuti banyak pameran, baik berkelompok maupun tunggal. Pada 9 April 1996, I Made Supena bersama beberapa seniman yang merupakan mahasiswa dari PSSRD UNUD dan STSI Denpasar, seperti
Setem, Sudana, Dewa Soma Wijaya, Diwa Rupa, Naya Swantha, Ketut Teler, Made Ardika, dan Galung Wiratmaja, mendirikan kelompok bernama Galang Kangin. Kelompok ini aktif menyelenggarakan beberapa pameran, performance art, dan diskusi-diskusi kesenirupaan. Selama dua puluh tahun berkarya, Supena mengelompokkan perjalanan berkaryanya dalam tiga periodisasi. Periode-periode tersebut oleh Supena dinamai sebagai periode tradisi, periode formal, dan periode emosi. Periodisasi tersebut bukan sebagai retrospektif, tetapi lebih menandai segala yang sudah dilakukannya.

Pertama, periode tradisi. Pada periode ini garis merupakan pijakan awal dari karya-karya Supena. Ia mengambil bentuk-bentuk wayang tradisional I Gusti Nyoman Lempad. Supena menganggap bahwa memberikan makna pada unsurunsur karya seni rupa sudah dianggap cukup. Selain unsur garis, unsur tradisi, seperti nilai-nilai dan bentuk-bentuk seni rupa tradisi (barong dan topeng), hadir sebagai inspirasi dari karya-karya Supena.

Kedua, periode formal dan presentasi. Pada periode ini Supena lebih menonjolkan aspek estetika formalisme sebagai pijakan karyanya. Unsur-unsur seni rupa seperti garis, warna, bidang, komposisi, tekstur, digali dan dipresentasikan dalam karya-karyanya yang menjadikan alam sebagai pijakan utama kekaryaannya. Pada karya ini teks rupa terkadang menjadi teks murni. Namun, tidak jarang ia dapat pula terbaca sebagai representasi alam. Karya-karya dalam periode ini, antara lain Landscape, Rentetan, serta seri lukisan Borobudur. Karya-karya Supena bergulat dan memaknai secara mendalam teks-teks rupa dengan meminjam objek-objek yang kemudian dapat dibaca sebagai representasi alam.

Ketiga, periode emosi. Pada periode ini karya-karya Supena hadir sebagai representasi atas kegelisahannya dalam memandang realitas sosial yang terjadi di masyarakat yang sedang bergejolak. Fenomena sosial-fenomena sosial tersebut, seperti gejala bunuh diri, konflik horizontal, dan carut-marut dunia politik. Secara emosional Supena terdorong menciptakan karya-karya tidak terbatas pada lukisan, tetapi juga karya tiga dimensional. Karya-karya dalam kelompok ini bersifat figuratif representasional. Artinya, ia tidak sebatas meminjam objek seperti pada kelompok formal tetapi juga memaknai objek itu sebagai ungkapan emosinya atas fenomena sosial yang terjadi di masyarakat. Pada periode ini terwujudlah beberapa karya lukisan, drawing, dan ratusan patung yang kemudian dipersentasikan menjadi karya-karya instalasi.

Melihat periodisasi dan perkembangan Supena dalam berkarya, terlihat bahwa ia merupakan salah seorang perupa penting dalam dunia seni rupa kontemporer Bali. Sebagai perupa, Supena cukup konsisten dalam mengembangkan karier kesenirupaannya. Sejak awal karier hingga kini, ia telah mengikuti beberapa pameran, baik berkelompok maupun tunggal. Sejak 1991-2009 ia tercatat telah 
mengikuti kurang lebih sembilan kali pameran tunggal, baik di Bali, Surabaya, maupun Jakarta. Pada tahun 2000 ia sempat pameran bertajuk Landscape Und Abstarction di Kota Frankfurt, Jerman. Disamping itu, Supena juga telah berpatisipasi dalam puluhan pameran bersama selama hampir 20 tahun karier kesenirupaannya.

Supena memperoleh beberapa penghargaan dari lembaga kebudayaan baik bersekala lokal, Nasional dan Internasional. Penghargaan-penghargaan tersebut, antara lain Philip Moris Art Award di Jakarta, Award of Excellence Bali, dan Prience Edward Island Canada. Selain berkiprah dalam dunia seni rupa kontemporer, Supena juga terlibat dalam beberapa aktivitas sosial. Ditengah kesibukannya sebagai perupa, Supena juga aktif dalam membangkitkan semangat para perupa Singapadu untuk berkiprah dalam dunia seni rupa kontemporer. Salah satu upaya itu adalah dengan menghimpun para perupa Singapadu yang terdiri dari para pelukis dan pematung untuk membentuk komunitas. Karya-karya mereka dipamerkan digaleri Santrian Sanur, pada 30 Oktober 2009. Pameran tersebut diselenggarakan dengan kurator Thomas U Frientag, seorang sejarawan seni asa Jerman yang telah lama bekerja sama dalam mengurusi karya-karya Supena.

Karya-karya Supena digali dari persoalan alam dalam kemasan formalisme estetik yang kuat, sehingga karya-karya tersebut pada periode abstrak merupakan representasi alam yang menyajikan tampilan karya yang kaya akan nilai estetis disamping pemaknaan yang dijanjikan dalam lukisannya. Selain alam, konsep karya Supena juga berkaitan dengan narasi sosial, terutama pada periode emosi yang banyak melukiskan anak-anak. Karya-karya pada periode tersebu merupakan representasi atas fenomena yang melanda sebagian anak-anak Indonesia, seperti bunuh diri dikalangan anak-anak, gizi buruk, dan mahalnya biaya pendidikan.

Proses kreatif Supena dimulai dari proses pencarian ide. Setelah itu, ide yang diperoleh dituangkan dalam bentuk sketsa untuk dipindahkan dalam kanvaskanvasnya. Selain melukis Supena juga menghadirkan karya-karya patung. Hal ini tidaklah mengherankan karena Supena mewarisi keahlian mematung dari ayahnya, I Ketut Muja. Karya-karya patung Supena juga hadir sebagai instalas yang dipresentasikan bersama dengan karya lukisnya. Dengan demikian, instalas Supena merupakan pengembangan dari kemampuan melukis sekaligus mematungnya. Supena juga menghadirkan beberapa karya performance untuk merespon karya instalasinya. Akibatnya, antara instalasi dan performance merupakan satu kesatuan.

Supena merupakan perupa yang menghadirkan hasil karyanya sebaga pernyataan personal. Karya-karya Supena menjanjikan pembacaan terhadap teks, nilai estetis yang secara kasat mata dapat dilihat oleh penikmat, dan terhadap konteks karya, yang merupakan suatu gagasan yang terkandung di balik setiap karya-karyanya. Dengan demikian, karya Supena memiliki sifat representatif yang dihadirkan melalui jalan puitis melalui bahasa rupa yang personal dan dalam.

Atas dasar itulah penulis merasa tertarik untuk menggali dan melakukan pembacaan terhadap biografi, konsep kreatif, proses kreatif, teks, dan konteks yang melekat pada karya-karya Supena. Penelitian ini juga dimaksudkan sebagai pendokumentasian kiprah kesenimanan Supena sebagai salah seorang perupa kontemporer Bali. Dengan demikian, tulisan ini diharapkan mampu menjadi sumbangan dokumentasi ditengah langkanya penelitian tentang para perupa kontemporer Bali.

\section{METODE PENELITIAN}

Penelitian ini merupakan penelitian deskriptif kualitatif terhadap karyakarya I Made Supena,yang meliputi karya-karya dua dimensi (lukisan) dan karyakarya tiga dimensi (instalasi dan patung). Jadi, subjek penelitian ini adalah karyakarya I Made Supena. Dalam mendapatkan dan mengumpulkan data, peneliti memakai instrumen penelitian berupa alat yang bisa merekam secara visual dan (atau) audio, yaitu kamera serta perekam suara. Pemeriksaanya berdasarkan foto dokumentasi, video dokumentasi, atau audio dokumentasi.

Karya-karya Supena tidak hanya dibaca dengan pendekatan tekstual semata (unsur-unsur rupa) tetapi juga melalui pendekatan kontekstual (muatan). Penelitian ini akan memaparkan tentang perupa I Made Supena yang meyangkut biografi, konsep kreatif, proses kreatif, periodisasi, teks dan konteks. Pemaparan tersebut berdasarkan pada konsep seni rupa tradisional, modern, kontemporer, biografi, serta semiotika dan estetika.

\section{HASILDAN PEMBAHASAN}

Singapadu adalah salah satu desa di Bali yang kaya dengan aktifitas kesenian, seperti seni tari, seni karawitan, dan seni rupa. Khusus di bidang seni rupa, desa ini dikenal sebagai pusat pembuatan topeng barong dan rangda yang cukup dikenal di Bali. Singapadu banyak melahirkan perupa, mulai dari yang otodidak hingga yang menempuh jalur akademis. Salah satu perupa akademis itu terlahir pada 12 Januari 1970 dari pasangan suami istri I Ketut Muja dan I Made Robin. Perupa itu adalah I Made Supena.

Sejak kanak-kanak Supena telah akrab dengan dunia kesenian, khususnya seni patung. Suara-suara pengotok dan pahat yang menghunjam batanganbatangan kayu telah terbiasa didengarnya. Hal ini sangat wajar, karena Supena terlahir dari keluarga seniman. Sang kakek, I Nyoman Doblogan, seorang undagi dan pematung. Sementara sang ayah, I Ketut Muja, adalah pematung yang handal dan terkenal lewat patung hanomannya. Patung Hanoman Muja memiliki ciri khas tersendiri seperti ekspresi gerak patung yang atraktif dan terkadang menonjolkan 
karakteristik kayu, misalnya dari segi serat dan bentuk kayu itu sendiri. Di dalam lingkungan keluarga yang seperti itulah darah seni Supena kecil terbentuk.

Jejak kesenimanan Supena dimulai sejak usia kanak-kanak. Setelah ia memasuki bangku sekolah menengah, Supena memutuskan menempuh pendidikan di SMIK, sekarang berubah menjadi SMK 2 Sukawati. Ia memilih program keahlian seni kriya kayu. Pada tahun 1991-1997 Supena melanjutkan studi di FSSRD Universitas Udayana mengambil Jurusan seni lukis.

Di kampus ia berhadapan dengan kaidah-kaidah akademik yang diserapnya dalam proses berkarya. Selama kuliah Supena mendapatkan ilmu serta wawasan seni rupa secara utuh. Ia menyerap segala bentuk kaidah-kaidah estetik barat, seperti komposisi, pewarnaan, keseimbangan, dan kesatuan. Kaidah-kaidah tersebut berpengaruh terhadap kecenderungan karyanya yang menunjukan kekuatan formalis.

Perjalanan kuliah Supena mengalami berbagai macam cobaan, salah satunya ketika ia mengalami kecelakaan berat, sehingga Supena terpaksa berhent beraktivitas selama setahun. Kondisi tersebut mempengaruhinya. Supena menjadi lebih tertutup dan merasa kesepian. Namun, hal ini tidak berlangsung lama. Supena akhirnya bangkit kembali dan berusaha untuk merintis karier kesenimanannya dengan mulai mengikuti beberapa pameran. Pada tahun 1991 , Supena mulai berpameran untuk pertama kalinya pada kegiatan Pesta Kesenian Bali (PKB) di Taman Budaya Denpasar. Dari sanalah awal Supena merintis karier di bidang seni rupa. Setelah itu, ia silih berganti mengikuti berbagai pameran, baik tunggal maupun berkelompok.

Salah satu upaya Supena untuk mengembangkan eksistensi diri dan kawan-kawannya, sesama perupa muda, adalah dengan menghimpun diri dalam kelompok yang diberinya nama Galang Kangin. Kelompok ini terdiri dari orangorang muda yang merupakan seniman-seniman lulusan dua perguruan tinggi berbeda, yaitu FSSRD (Unud) dan STSI Denpasar (kini ISI Denpasar). Di dalam catatan, kelompok ini berdiri pada 9 April 1996 dengan anggota terdiri dari I Made Supena, I Dewa Gede Soma Wijaya, I Wayan Naya Swantha, Galung Wiratmaja (FSSRD Unud), I Wayan Setem, I Ketut Teler, I Nyoman Diwarupa, I Made Ardika (petruk), dan I Made Sudana (koplek) (STSI Denpasar). Pada saat terbentuknya kelompok ini, Galang Kangin diketuai I Wayan Setem.

Pendirian kelompok Galang Kangin dilatarbelakangi oleh berkembangnya isu-isu penggabungan dua institusi seni, yaitu Program Studi Seni Rupa dan Desain (PSSRD) Universitas Udayana dan Sekolah Tinggi Seni Indonesia (STSI) Denpasar. Banyak kalangan tidak menyepakati penggabungan itu karena latarbelakang dan sistem yang dianggap tidak sama. Untuk menepis opini yang menganggap penggabungan itu sebagai hal yang sulit, sejumlah mahasiswa dari dua institusi itu mendahuluinya menjawab bahwa mereka dapat "seirama" dalam menjaga visi kesenian.

Galang Kangin disepakati sebagai nama komunitas itu. Nama tersebut berarti “cahaya diufuk timur." Dalam pemahaman yang luas, Galang Kangin dapat dimaknai sebagai memulai sesuatu dengan benar berdasarkan permulaan waktu kerja. Ketika fajar mulai merah di ufuk timur, ia merupakan sebintik cahaya yang sehat, hangat, dan segar. Nama itu dapat juga diartikan sebagai kebijaksanaan atau pengetahuan dari timur.

Supena sendiri memiliki kesadaran sosial yang tinggi terhadap desanya. Hal itu ia tunjukkan dengan mendirikan sebuah kelompok yang menaungi para perupa di Singapadu, baik pelukis, pematung, pembuat topeng, maupun sangging barong. Mereka berasal dari segala lapisan usia, baik yang muda maupun yang sudah senior. Kelompok itu diberi nama Perupa Singapadu dan diketuai sendiri oleh Supena. Kelompok ini mengadakan pameran perdananya di Gallery Santrian Sanur, pada 30 Oktober 2009.

Supena terus menapaki perkembangan kekaryaannya. Suami dari Ni Wayan Sukantri (33 tahun) serta bapak dari tiga orang putra-putri, yaitu Ni Putu Sanjiwani (11 tahun), Ni Made Laras Wangi (9 tahun), dan I Komang Bayu Gana Arta (3 tahun) ini selalu berkarya untuk memenuhi hasrat estetikanya. Menurut Supena kesenian merupakan kebutuhan jiwa. Oleh karena itu, pada setiap kesempatan Supena selalu berada di studio, yang sekaligus menjadi rumahnya di Banjar Mukti, Singapadu, Gianyar. Iklim berkesenian sangat terasa di studio. Di tempat itu ia tidak bekerja sendiri. Bersama ayah, kakak, adik, dan iparnya, Supena terus mengembangkan kreativitasnya, baik secara individu maupun sebagai sebuah keluarga seniman.

Sang ayah, I Ketut Muja (66 tahun), merupakan seorang pematung senior yang dimiliki Desa Singapadu. I Ketut Muja dikenal sebagai spesialis pematung Hanoman yang memiliki kecenderungan ide penggarapan dengan konvensi tradisi. Ia memiliki gaya atau corak khas yang kemudian menjadi identitas dirinya. Di samping itu, ia juga sering membuat patung dengan mengekspos karakter struktur bahan, yaitu kayu sebagai media utama. Ia membiarkan bentuk asli kayu sebagai struktur-struktur dasar bentuk patungnya, sehingga sekilas patungnya tampak ganjil, magis, dan memiliki nafas-nafas surealistik.

Saudara Supena yang paling sulung, I Wayan Jana (42 tahun), juga memiliki kecenderungan berkarya seni patung. Perupa yang pernah mengenyam pendidikan di ISI Yogyakarta (1990-1992) ini hadir dalam karya-karya yang akademis. Ia menyerap kaidah-kaidah estetika patung modern, terutama corak figuratif yang khas seperti penghadiran figur-figur wanita yang telah mengalami distorsi dan stilirisasi. Hal tersebut terjadi karena pengaruh dari dunia akademi yang pernah ditempuhnya. Tak seperti patung sang ayah yang terkesan magis dan religius, patung Jana terasa elegan, figuratif, dan mengalami stilirisasi. Bentuk 
yang mengesankan formalisme estetik terlihat pada figur-figur perempuan yang mengalami penyederhanaan bentuk, sehingga patung Jana terlihat lebih minimalis.

Adik Supena yang menekuni seni lukis adalah I Ketut Sugantika. Ia akrab disapa Lekung oleh kawan-kawannya. Sugantika adalah anggota dari kelompok Hitam-Putih. Tak seperti sang kakak yang lebih menekuni abstrak, Sugantika memiliki kecendrungan rupa yang realis. Sugantika merupakan pelukis muda yang dikenal sering mengangkat bentuk-bentuk babi sebagai "ikon" dalam karyanya. Ia juga sering melakukan eksperimen visual melalui karya instalasi lukisan. Salah satu karyanya berjudul Mengatur Pikiran berupa penggabungan karya lukis dan video.

Sang ipar, Ni Nyoman Sani kelahiran Sanur, yang merupakan istri dari Sugantika juga menekuni seni lukis. Karya-karya Ni Nyoman Sani menyangkut figur-figur wanita dalam baluran fashion. Karyanya terkesan sederhana non-realis dan mengalami distorsi bentuk. Sani tergabung dalam kelompok Hitam Putih. Dari gambaran di atas terlihat bahwa Supena memang berada dalam lingkungan seniman yang kuat.

Supena adalah perupa yang telah malang melintang di dunia seni rupa Bali. Supena telah melakukan berbagai pameran baik pameran tunggal maupun pameran bersama. Tidak kurang dari sembilan kali pameran tunggal pernah digelarnya baik di Bali, Jakarta, Yogjakarta, maupun luar negeri. Pada 1998 ia mulai pameran tunggal perdananya di Gallery The Chendi Payangan Gianyar Bal dan kemudian disusul pada pameran tunggal keduanya pada 1999 yang berjudul Reality of Abstract Painting di Taman Budaya Art Center Denpasar. Pada tahun 2000 Supena dan kawannya, Susena, berkesempatan mengadakan pameran berdua di Frankfrut Jerman dalam sebuah pameran yang bertajuk Landscape UndAbstraction.

Pada 2002 Supena mengadakan dua kali pameran tunggal, yaitu di Suli Art Gallery Denpasar dengan tajuk New Painting. Setelah itu, pameran di Gallery Moon Décor Jakarta bertajuk About Nature. Berikutnya pada 2004 ia pameran tunggal di Ganesha Gallery Jimbaran Bali bertajuk The Likeness of Nature. Pada 2005 ia pameran di Danes Art Veranda Denpasar berjudul Studi Alam Supena. Pada 2007 ia merambah kota Surabaya tepatnya di Gracia Gallery dengan judu pameran Landscape I Made Supena. Setahun kemudian ia menghadirkan pencapaian kreatifnya di Santrian Gallery Sanur. Saat itu, ia menyelenggarakan pameran berjudul Emotion. Pada 2010 Supena memamerkan karya-karyanya di Jogja Gallery dengan judul Geneologi.

Tidak hanya pameran tunggal yang telah digelar, pameran bersama pun sangat sering diikutinya. Kurang lebih 59 kali Supena mengikuti pameran bersama. Sejak 1991 dan 1992 ia mengikuti pameran bersama dalam Pesta
Kesenian Bali (PKB) di Taman Budaya Denpasar. Pada 1993 ia menggelar dua kali pameran bersama yaitu, pameran serangkaian HUT PSSRD Universitas Udayana yang ke-10 serta pameran bersama Master-Student, serangkaian Peksiminas di STSI Denpasar. Setahun kemudian Supena kembali mengikuti pameran PKB di Taman Budaya Denpasar serta melaksanakan pameran bersama di Gallery Puri Bukit Mas, Peliatan Ubud. Setelah itu pada 1995 ia menggelar pameran bersama "Group 14" di Art Center Denpasar. Pada 1996 tidak kurang dua event pameran bersama ia ikuti, yaitu pameran bersama HMJS PSSRD Universitas Udayana di Museum Sidik Jari Denpasar serta pameran bersama kelompok "Galang Kangin" di Museum Bali.

Pada 1997 Supena mengikuti empat kali pameran bersama, Philip Moris1997 di Museum Arma. Masih dalam ajang yang sama Supena mengikuti pameran bersama para finalis Philip Moris di Jakarta. Selanjutnya ia kembali berpartisipasi di ajang pameran PKB di Art Center Denpasar. Selain itu, ia juga mengikuti pameran Gelar Seni Lukis 1997 di Art Center Denpasar. Pada 1998 ia mengikuti sebelas kali pameran bersama yang diikuti, yaitu Exhibition 21 di Gallery Sahadewa Batuan, Wort Art di Art Center Denpasar Bali, pameran bersama di Gallery Ch. Fahrenhorst Helmeln Jerman, pameran bersama di Collection of the place Bandung, pameran di The Chedi Payangan, pameran sketch dan Drawing di Art Center Denpasar, pameran Refleksi 1998 di Darga Gallery Sanur, pameran di Duta Fine Art Jakarta dan pameran Philip Moris 1998 di Gallery Nasional Jakarta. Selama 1999 Supena menggelar empat kali pameran bersama, yaitu pameran Koleksi, Museum Sidik jari, pameran di Museum Fur Volkerkunde, Frankrut Jerman, pameran bersama " 40 " besar Indonesia, Windos/Newton di Gallery Widayat, Pameran \& Perupa Bali di TMI Jakarta.

Pada 2000 Supena menghadirkan tiga kali pameran bersama, yaitu Millenium Exhibition SDI di Museum Neka Ubud, Refleksi Seni II di Darga Gallery Sanur, Landscape Art Weitkulturen, Frankrut Jerman. Setelah itu, pada 2001 Supena mengikuti empat kali pameran bersama, yaitu pameran Narcicisme di Museum Sidik Jari Denpasar, pameran Philip Morris Art Award 2001 di Gallery Nasional Jakarta, pameran Cine and Clour di Art Center Denpasar, pameran BaliInsel der geother moerfelden di Walldort Jerman. Pada 2002 Supena mengikuti tiga kali pameran bersama, yaitu pameran Galang Kangin 2002 di Art Center Denpasar, Workshop Galang Kangin di Tejakula Buleleng, dan pameran Festival Seni Perdamaian di Art Center Denpasar.

Pada 2003 Supena mengikuti empat aktivitas pameran bersama, yaitu In Love with Canvas di Gallery Montik Jakarta, Aestetic and Nature di Griya Santriyan Gallery Sanur, The Silent Painting di Griya Santrian Sanur serta Narasi Abstrak di Gallery Millenium, Jakarta. 
Lima kali pameran bersama diikuti pada 2004. Pameran tersebut, antara lain Journey to Foreign Land di Santriyan Gallery Sanur, Bali Temptation di Sanggam Gallery Yogya dan V Gallery Jakarta, Natah Tanah di Pilar Batu Gallery Ubud. Membaca Tri Hita Karana di Millenium Gallery Jakarta, Supena juga pernah mengadakan pameran patung bersama yang berjudul Konstruksi Patung di Paros Gallery Sukawati, Gianyar. Pada 2005 Supena disibukkan dengan tujuh kali pameran bersama, yaitu Intermezo di Langgeng Gallery Yogyakarta, Power ofmind di Orasis Gallery Surabaya, Pameran Himpunan Pelukis Gianyar di Gallery Astra Jakarta atau Hotel Niko Jakarta, Pameran Serupa di Griya Santriyan Sanur, "Bali Bienale" di Arma Museum Ubud.

Sepanjang 2006 Supena mengikuti tiga kali pameran bersama, yaitu Beving Realisme di V Gallery Yogyakarta, Triumph and Deafeat bersama kelompok Galang Kangin di Santrian Gallery Sanur, Spirit of Bali di Damping Gallery Ubud. Pada 2007 pameran yang diikuti, antara lain Triumph and Deafeat bersama Galang Kangin di Taman Budaya Yogyakarta. Thousand Mystery of Borobodur di Jogja Gallery Yogyakarta, White Painting di Santrian Gallery Sanur, Portofolio di Jogja Gallery Yogyakarta, Love Leather di Tony Raka Mas Ubud, Shadow of Prambanan di Jogja Gallery.

Pada 2008 Supena mengikuti tiga kali pameran bersama, yaitu 100 tahun Kebangkaitan Nasional di Jogja Gallery, Entitas Nurani Art Center Denpasar, Bal Art Now Hibilding Jogja Gallery. Tiga kali pameran bersama dilaksanakan pada 2009, yaitu Fresh 4 You di Jogja Gallery, Expectation bersama Galang Kangin and friends di Toni Raka Mas Ubud, serta pameran ilustrasi kompas di Bentara Budaya Jakarta. Pada 2010 Supena hingga saat penelitian ini ditulis sudah melaksanakan tiga kali pameran bersama, yaitu Singapadu A Vilage Creates It Self bersama perupa Singapadu, Return toAbstraction di Tony Raka Ubud, serta "KUTA" pameran bersama Galang Kangin di Gaya Fushion Art Space Ubud. Tak hanya malang-melintang di dunia pameran lukisan ataupun patung, Supena merupakan perupa yang selalu mengembangkan gagasan-gagasannya ke bentuk-bentuk ekspresi rupa yang lain. Instalasi dan performance art juga sering digeluti Supena.

Pada 1995 Supena dan kawan-kawannya semasa kuliah di PSSRD Unud pernah menggarap proyek instalasi Eksperimental Art di UNS, Solo. Kemudian pada 1998 ia pernah menggarap instalasi bertajuk black and white bersama kelompok (STBC, Mukti) di Art Center Denpasar serta menggarap performance art yang bertajuk Taman Sri Wedari bersama kelompok (STBC Mukti) di Sahadewa Gallery Batuan.

Pada 2004 ia menggarap performance Doa pada Laut (Jala Art) di panta Serangan Badung. Pada 2005 Supena bersama Suklu dan Polenk Rediasa, mengarap instalasi bertajuk "Ritus Totem Stimulus" di area Sector Golf Sanur, kemudian masih pada 2005 Supena adalah salah satu partisipan dalam proyek performance Nyoman Erawan yang berjudul Maha Pralaya serta Megalitichum Quantum di GWK Badung, serta proyek instalasi RTRWP kolaborasi bersama kelompok Galang Kangin dan bunyi batu di rumah Buku Cengkilung Denpasar. Pada 2006 Supena bersama kelompok Galang Kangin merayakan 10 tahun berdirinya kelompok ini dengan menghadirkan instalasi 1000 pamer di RBC Cengkilung Denpasar.

Supena merupakan perupa Singapadu yang dikenal sebagai perupa yang intens menghadirkan representasi alam dalam karya-karyanya. Ia lebih dikenal sebagai perupa abstrak dengan representasi alam sebagai indentitas personalnya. Namun, sebagai perupa yang selalu bergerak dalam pencarian karya, Supena tidak hanya berhenti pada bentuk abstrak saja tetapi juga berkarya dengan menghadirkan ikon-ikon seni tradisi dan representasi obyek dengan pendekatan realistik, khususnya pada karya dalam seri emosinya.

Berdasarkan pemaparan pada bab sebelumnya yang membahas Supena dari sisi biografis, konsep karya, proses kreatif, periodisasi, serta pembacaan teks dan konteks karya Supena maka dapat disimpulkan beberapa hal sebagai berikut.

Biografi I Made Supena. Secara biografis Supena terlahir dari keluarga seniman yang mewarisi bakat kesenian sang ayah, I Ketut Muja, seorang pematung otodidak. Saudara-saudara Supena yang lain, seperti Wayan Jana dan I Ketut Sugantika Lekung, serta adik iparnya, Ni Nyoman Sani, juga menekuni dunia kesenirupaan baik sebagai pelukis maupun pematung yang ikut meramaikan kancah seni rupa Bali. Sebagi seorang perupa akademis yang menepuh pendidikan formal kesenirupaan di PSSRD Unud pada 1991-1997, Supena menjadi salah satu perupa Bali yang telah berpengalaman di dunia seni rupa Bali, bahkan di Indonesia. Tidak kurang dari sembilan kali pameran tunggal ia jalankan, mulai dari Bali, Jakarta, Yogyakarta hingga Jerman. Ia juga melakukan tidak kurang lima puluh delapan kali pameran bersama selama rentan waktu 1991 hingga sekarang.

Konsep Karya I Made Supena. Secara konseptual Supena menghadirkan karya-karya yang berasal dari kegelisahan yang dirasakan dari dalam dirinya terhadap suatu obyek ataupun fenomena sosial. Konsep karya Supena bergerak antara menghadirkan representasi alam dalam bungkusan formalistik estetis, terutama pada karya-karya abstraknya, serta menghadirkan represenatasi sosial pada karya seri emosinya. Ia juga sering menghadirkan karya tradisi yang secara konseptual merupakan bentuk kerinduan personalnya terhadap penjelajahan estetis terutama karakter garis pada karya-karya lukis tradisi.

Proses kreatif I Made Supena. Proses kreatif Supena berawal dari ide yang "mengganggu" dan menggelitik naluri estetisnya kemudian ia visualisasikan ke dalam karya-karya sketsa sebagai sebuah studi rupa, baik tentang alam maupun representasi sosial, kemudian dieksekusi di atas kanvas ataupun kayu. Melalui proses kreatifnya, Supena tidak hanya menghadirkan karya dua dimensi, tetapi 
juga merambah seni rupa tiga dimensi, berupa patung yang kerap direpresentasikan bersamaan dengan karya lukisannya, sehingga menjadi sebentuk karya instalasi. Ketertarikan Supena pada karya seni patung dilatarbelakangi oleh garis keturunan sang ayah yang seorang pematung serta latar belakang pendidikan menengahnya, yaitu SMKN 2 Sukawati, yang mengambil Jurusan Seni Kriya Kayu. Kondis tersebut menjadikan ia dan patung memiliki hubungan personal yang erat. Supena juga sering menghadirkan karya yang digali dari khasanah kosa rupa tradisi.Hal ini didorong oleh kekaguman dirinya atas karya-karya I Gusti Nyoman Lempad.

\section{Periodisasi Karya I Made Supena.}

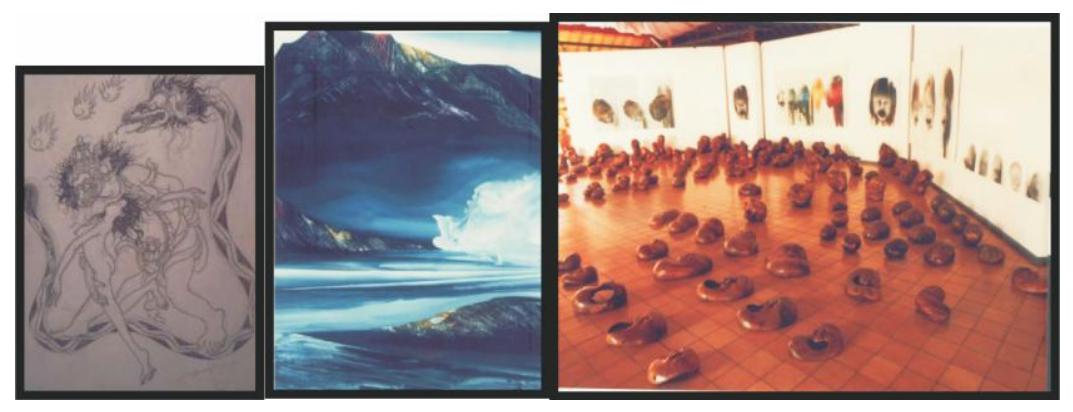

Gambar 1. Pertemuan Ibu Pertiwi, Mengenang Kedalaman, Emosi, Tinta di atas Kertas, Akrilik pada Kanvas, Kayu Suar, Kayu Sonokling, Kayu Kamboja, 32 × 24 cm, 120 x $180 \mathrm{~cm}$, Sumber: Pameran Tunggal, Geneologi I Made Supena, di Jogja Gallery.

Supena adalah perupa yang selalu bergerak dalam pencarian-pencarian gagasan. Selama dua puluh tahun kekaryaannya di dunia seni rupa, Supena telah melahirkan ratusan karya yang secara umum dapat dikelompokan dalam tiga periodisasi, yaitu tradisi, formal, dan emosi. Namun, periodisasi ini diakui Supena bukanlah pengelompokan secara retrospektif yang dapat dibagi dalam waktu tetapi tiap-tiap periodisasi selalu datang silih berganti secara ulak-alik sesuai kerinduan dirinya untuk berkarya dalam tiga kecenderungan tersebut.

Dalam periode tradisi, karya-karya Supena menghadirkan seni lukis wayang tradisi yang bertujuan sebagai upaya Supena untuk memahami persoalan garis yang menarik dalam seni lukis tradisi. Kecenderungan ini terkait dengan karakteristik garis yang konstan dan kuat, seperti yang terlihat pada karya-karya I Gusti Nyoman Lempad yang sangat dikagumi Supena. Dalam periode formal, Supena menghadirkan gubah rupa abstrak yang merupakan representasi alam yang dibungkus dengan kaidah-kaidah estetika formal. Dalam periode emosi Supena menghadirkan representasi sosial melalui penghadiran obyek bayi yang merupakan representasi atas maraknya fenomena sosial, seperti bunuh diri di kalangan anak-anak, mahalnya biaya pendidikan dan kesehatan, serta fenomenafenomena yang kerap muncul mengusik batinnya.

Pembacaan Karya I Made Supena Teks dan Konteks. Teks adalah kombinasi tanda-tanda, baik verbal maupun visual. Hardiman (2010: 12) menyatakan bahwa teks dalam penggunaan sehari-hari menunjuk pada tulisan dalam berbagai bentuknya, seperti buku dan majalah. Akan tetapi, dalam kajian budaya (cultural studies) telah menjadi sebuah aksioma bahwa teks merupakan segala sesuatu yang menghasilkan makna melalui praktik pemaknaan. Dengan demikian pakaian, citra, peristiwa, olahraga, bintang pop, dan lain-lain dapat dibaca sebagai teks.

Dalam sebuah karya seni rupa teks-teks hadir dalam citraan visual. Teksteks tersebut dapat saja hadir sebagai bentuk representasi dari suatu narasi yang sangat berjarak dengan teks tersebut, bahkan ia dapat berbicara tentang persoalan di luar kesenirupaan. Hal inilah yang dapat dimaknai sebagai konteks dalam sebuah karya seni rupa.

Karya seni rupa dalam kehadirannya selalu membawa muatan. Muatan tersebut dapat berupa muatan tekstual dan kontekstual. Muatan tekstual adalah kandungan isi sebuah karya yang didalamnya menyangkut hal-hal yang bersifat estetis. Dalam muatan tekstual sebuah karya hadir sebagai ungkapan murni, yang mempersoalkan unsur-unsur rupa itu sendiri, misalnya garis, warna, bidang, tekstur, volume, komposisi, keseimbangan, serta kesatuan. Dalam muatan tekstual sebuah karya seni hadir tanpa pretensi untuk menyampaikan pesan di luar persoalan seni rupa.

Sementara itu, muatan kontekstual merupakan kandungan karya seni rupa yang berupa pesan atau narasi, yang ada di balik sebuah karya rupa. Dalam wilayah ini sebuah karya rupa tidak hanya berhenti pada ungkapan estetis, tetapi sekaligus membawa pesan atau narasi di luar persoalan seni rupa. Akibatnya, karya seni rupa hadir sebagai representasi atas persoalan di luar seni rupa yang menyeret ke dalam pemaknaan. Karya seni rupa pada akhirnya tidak berhenti dalam sifatnya yang reflektif.

Dalam beberapa karya Supena, kedua muatan tersebut hadir secara bersamaan tetapi ada beberapa karyanya yang murni sebagai ungkapan tekstual yang menyangkut formalisme estetis didalamnya. Dalam sub bab ini penulis mencoba membaca beberapa karya Supena terkait dengan nilai teks ataupun kontekstualnya. Karya-karya Supena dalam ketiga kecenderungan periodisasi yakni tradisi, formal, dan emosi 


\section{Periodisasi Tradisi}

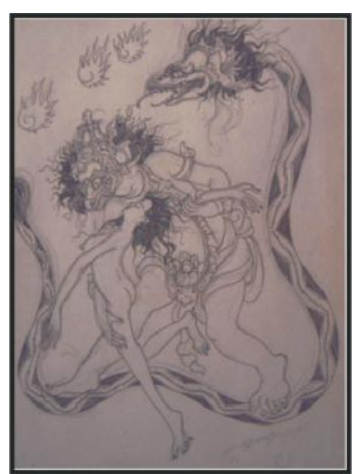

Gambar 2. Pertemuan Ibu Pertiwi

Tinta pada Kertas, 32 × $24 \mathrm{~cm}, 2002$.

Sumber: Katalog Pameran Tunggal, Geneologi I Made Supena, di Jogya Gallery

Pertemuan Ibu Pertiwi (2002) merupakan karya Supena yang menghadirkan karakteristik seni lukis tradisi Bali. Dalam karya tersebut garis menjadi kekuatan utama, tarikan garis yang konstan dan terkontrol menjadi karaktristik karya tersebut yang Supena adopsi dari Gusti nyoman Lempad. Karya ini memisualisasikan sosok Dewa Wisnu yang menjelma menjadi siluman Babi bertemu dengan Dewi Pertiwi. Pertemuan kasih antara keduanya ini kemudian melahirkan sosok raksasa Boma. Karya ini adalah bentuk visualisasi yang menggiring makna kontekstual tentang kesuburan, yakni bertemunya sosok Purusa dari (Wisnu) dengan sosok Pradana (Pertiwi).

\section{Priodesasi Formal}

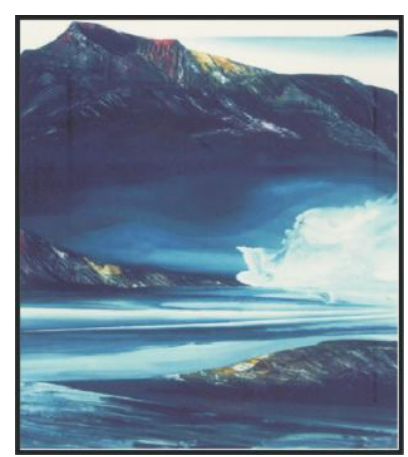

Gambar 3. Mengenang Dalam Kedalaman Akrilik pada Kanvas, 180 x 120 cm, 2007

Sumber Foto: Katalog Pameran Tunggal, Geneologi I Made Supena, di Jogja Gallery.
Melalui karya Mengenang Dalam Kedalaman, Supena menghadirkan lanskap gunung yang teramat kontemplatif dan puitik. Ia menghadirkan abstraksi gunung dengan tekstur semu melalui kerokan palet yang terkesan padat dan kuat diantara sapuan awan memutih terkadang membiru menyelimuti gunung menimbulkan kesan meditatif. Ada kedalaman yang dihadirkan secara puitik. Efek abstraksi tersebut dihadirkan dalam balutan background yang flat putih dan terkesan tenang mendukung kedalaman yang hendak ia bangun. Nada warna coba ia hadirkan dengan memberikan aksen-aksen merah dan kuning pada puncak gunung yang memberikan irama visual yang menarik.

\section{Periodesasi Emos}

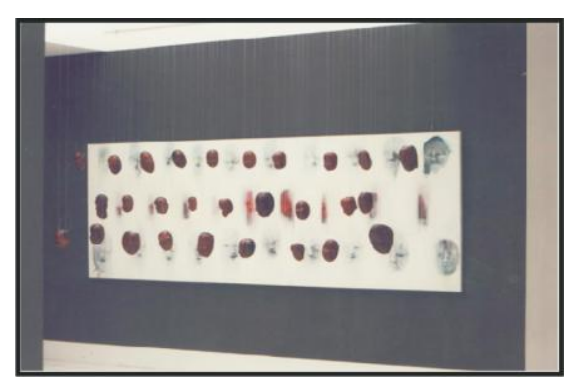

Gambar 4. In The White,

Akrilik pada kanvas, 150 x $400 \mathrm{~cm}$ dan 26 patung, 2009

Sumber Foto: Proposal Pameran Tunggal, Geneologi I Made Supena, di Jogja Gallery.

In The White (2009) merupakan karya Supena yang menghadirkan presentasi lukisan dan patung-patung. Patung-patung kepala bayi yang berjumlah dua puluh enam buah bergelantungan di depan bidang kanvas berukuran 150 x 400 $\mathrm{cm}$ yang juga menghadirkan wajah-wajah bayi yang cenderung abu-abu yang monochrome tersapu oleh latar putih flat yang bersih. Jarak antara karakteristik tiga dimensional pada patung dengan karakteristik dua dimensional pada lukisan coba untuk dicairkan oleh Supena dalam karyanya. Hal ini menjadikan karya Supena menjadi instalasi lukisan dan patung yang mencoba mempertanyakan batasan-batasan antara seni lukis dan seni patung itu sendiri.

\section{PENUTUP}

I Made Supena adalah perupa yang sudah melalang melintang selama kurang dari 20 tahun berdirinya seni rupa Bali. Secara geografis Supena terlahir dari ayah, I Ketut Muja, seorang pematung yang terkenal. Sementara kakaknya, I Wayan Jana juga merupakan pematung akademis yang pernah menempuh pendidikan di Yogyakarta. Adiknya, I Nyoman Lekung Sugantika, merupakan 
100 imasi, Vol. 12, No. 1, Februari $2014: 85$ - 100

seorang pelukis Jurusan ISI Denpasar, sedangkan iparnya, Ni Nyoman Sani, juga seorang pelukis.

Konsep karya Supena beranjak dari persoalan alam yang dituangkan dalam karya-karyanya. Proses kreatif I Made Supena ditandai oleh periodisas karyanya yakni tradisi, formal, dan emosi. Sedangkan karya Supena dapat dibaca dalam persepektif teks rupa melalui kuatnya unsur-unsur formal dalam karyanya.

Karya Supena juga dapat dibaca konteksnya sebagai sebuah pemaknaan terhadap obyek ataupun teks-teks rupa yang dihadirkan.

\section{KEPUSTAKAAN}

Bugin, Burhan (Ed.). 2004. Metode Penelitian Kualitatif: Aktualisasi Metodologis ke Arah Ragam Varian Kontemporer. Jakarta: PT Raja Grafindo Persada.

Bugin, Burhan. 2005. Analisis Data Penelitian Kualitatif.Jakarta:Grafindo

Freitag, U Thomas, 1999. Reality of Abstract Painting I Made Supena. Bali: PT Dian Rakyat.

Hardiman. 2010. I Made Supena genealogi:Katalog Pameran Tunggal. Yogyakarta: Jogja Gallery.

Sukra, I Wayan. 2005. Katalog Pameran Serupa. Bali: Satrian Gallery.

Supena, I Made, dkk. 2009. Singapadu A Village Creates it Self. Bali: Santrian Gallery.
TENUN GRINGSING

\section{KORELASI MOTIF, FUNGSI, DAN ARTI SIMBOLIK}

Sri Utami

Mahasiswa Pascasarjana ISI Yogyakarta

Email: tamiebalie@gmail.com

\section{Abstrak}

Penelitian ini bertujuan mendeskripsikan tenun gringsing, baik dari sisi korelasi motif, fungsi, maupun arti simboliknya. Hasil penelitian sebagai berikut. Kain tenun Gringsing terdapat di desa Tenganan, Pegringsingan, Karangasem, Bali.Tenun Gringsing tergolong dalam Wastra Wali atau Kain Bebali (Kain Bali) sebagai kain sakral yang sangat sederhana baik dalam penampilan maupun pembuatannya. Berbagai kain tenunan hasil produksi masyarakat Tenganan Bali, tidak hanya digunakan sebagai pakaian saja tetapi juga dikaitkan dengan berbagai kepercayaan. Ia ikut mengiringi berbagai ritual keagamaan, adat, dan daur hidup manusia. Di samping itu, kain Bali, khususnya kain Gringsing, dipercaya sebagai sarana pengobatan. Kain ini dianggap sakral karena dipercaya dapat memberikan petuah, petunjuk, harapan, dan kesembuhan. Kesemuanya diungkapkan dengan berbagai nama, warna, corak, dan ragam hias kain.

Kata kunci: Tenun Geringsing, motif, fungsi, arti simbolik

\section{GRINGSING WOVEN CLOTH: THE MOTIF CORRELATION,}

FUNCTION, AND SYMBOLIC MEANINGS

\section{Abstract}

This research aims at describing Gringsing woven cloth in terms of the motif correlation, function, and simbolic meanings. The results of the research show that this kind of cloth can be found in Tenganan, Pegringsingan, Karangasem, Bali. It belongs toWastra Wali orBebali cloth which is considered sacred. It is very simple both in its appearance and creation. Many kinds of woven cloth made by the people in Tenganan, Bali are used not only for clothing but also for being connected to their beliefs. They are used in many religious rituals and customs, and they also witness the cycles of the lives of human beings. Besides, Balinese cloth, especially Gringsing cloth, is believed to be a kind of medium for medication. Thus, this cloth is considered sacred because it is believed to be able to give advices, guidance, hopes, and also healing. All of these are expressed through many kinds of name, color, motif, and ornaments.

Key words: Gringsing woven cloth, motif, function, and symbolic meanings 


\section{PENDAHULUAN}

Dalam sejarahnya, masyarakat Bali dibagi menjadi dua golongan, yaitu Bali Hindu dan Bali Aga. Masyarakat Bali Hindu merupakan keturunan warga Majapahit yang hijrah ke Bali abad ketigabelas. Sebelumnya hubungan antara Bali dan Majapahit di Jawa Timur telah terjalin. Sejak abad kesepuluh raja Dharma Udayana dari Bali mengambil permaisuri dari Jawa Timur bernama Mahendradatta (bergelar Sri Guna Prya Dharmapatni) yang merupakan keturunan Mpu Sendok. Perkawinannya melahirkan Raja Erlangga yang kemudian dinobatkan menjadi raja Jawa Timur menggantikan Raja Sri Dharmawangsa yang memerintah pada 991-1007. Ketika kerajaan Majapahit mengalami kemunduran dan keruntuhan, mereka setia membawa sisa-sisa kerajaan Majapahit dan agama Hindu menyingkir ke arah timur hingga ke Pulau Bali (Kartiwa, 2007: 79).

Masyarakat Bali-Hindu yang merupakan bagian terbesar penduduk Bali, pada umumnya, mendiami daerah dataran hingga bagian barat Pulau Lombok. Mereka mengenal sistem pelapisan struktur sosial berdasarkan keturunan kelompok-kelompok kerabat yang bersifat patrinial atau kasta. Berdasarkan proses sejarah tersebut maka struktur masyarakat Bali tersusun ke dalam pelapisan tinggi rendah yang dipengaruhi sistem kasta dari agama Hindu kuno, yaitu Brahmana, Ksatria, Vaisya, dan Sudra. Ketiga pelapisan pertama disebut Triwangsa dan lapisan keempat disebut jaba. Hanya sebagian kecil dari masyarakat Bali yang termasuk golongan Triwangsa. Sebaliknya, sebagian besar masyarakat Bali termasuk wangsa jaba. Merekalah mayoritas penduduk Bali. Sistem pelapisan sosial ini berpengaruh dalam adat-istiadat, sikap pergaulan, dan tata bahasa. Meskipun demikian, perbedaan pelapisan ini tidak berpengaruh terhadap sistem cara berpakaian.

Sementara itu, masyarakat Bali-Aga kurang mendapat pengaruh JawaHindu dari Majapahit. Oleh karena itu, masyarakat Bali-Aga mempunyai budaya yang berbeda dengan Bali Hindu yang ada di dataran. Masyarakat yang tergolong Bali-Aga mendiami desa-desa pegunungan sekitar Sembiran, Cempaga, Sidatapa, Pedawa, Tigawangsa di kabupaten Buleleng, dan desa Tenganan Pagringsingan di kabupaten Karangasem (Kartiwa,2007: 80).

Desa Tenganan Pagringsingan merupakan salah satu dari beberapa desa kuno di Bali. Desa ini terletak di Kecamatan Manggis kabupaten Karangasem, tepatnya di sebelah timur pulau Bali. Penduduk Desa Tenganan adalah suku asli Bali yang hingga kini masih tetap mempertahankan tatanan kehidupan tradisional Kehidupan sosial-budaya, keagamaan, dan adat-istiadat dijalankan berdasarkan awig-awig adat yang telah disahkan dan disepakati bersama sejak zaman nenek moyang mereka.

Kata Tenganan berasal dari kata "tengah" atau "ngatengahang" yang berarti "bergerak ke daerah yang lebih dalam". Penurunan kata ini berhubungan dengan pergerakan orang-orang desa dari daerah pinggir pantai ke daerah pemukiman, yang terletak di tengah-tengah perbukitan, yakni Bukit Barat (Bukit Kauh) dan Bukit Timur (Bukit Kangin). Kata Pegeringsingan diambil dari kata "geringsing". Geringsing merupakan produk tenun tradisional yang hanya dapat ditemukan di Desa Tenganan Pegeringsingan. Gerinsing dianggap sakral dan diyakini dapat menjauhkan kekuatan magis jahat atau black magic. Geringsing berasal dari kata "gering" yang berarti sakit dan "sing" yang berarti tidak. (wawancara dengan Putu Sujana,10 Mei 2011). Nama-nama kain Gringsing yang tergolong dalam jenis Bebali atau Wastra Wali diambil dari alam sekitar serta berupa kata-kata mutiara dan nama-nama dari tampilan fisik tenunannya.

\section{PEMBAHASAN}

\section{Tenun Gringsing}

Menenun merupakan salah satu teknik pembuatan kain yang telah ada sejak berabad-abad lalu. Budaya menenun tumbuh dan berkembang di berbagai tempat bersamaan dengan peradaban manusia dan kebudayaan di daerah setempat, begitu pula dengan warna dan ragam hias atau corak dari hasil tenunan mempunyai kekhasan tersendiri di setiap daerah. Sebagaimana daerah lain di Indonesia, Bali juga memiliki kain tradisional berupa kain tenun yang menjadi kebanggan masyarakat Bali, yaitu kain tenun gringsing yang dihasilkan oleh masyarakat BaliAga Tenganan Pagringsingan, Karangasem.

Tenun gringsing atau wastra gringsing adalah salah satu kain tradisional khas Bali yang terbuat dari benang kapas dengan ragam hias motif yang dibentuk dari dobel ikat atau tenun ganda, yaitu mengikat benang lungsi dan benang pakan sekaligus. Pembuatannya memerlukan waktu yang cukup lama, mulai satu hingga lima tahun dan dilakukan dengan teknik khusus yang sangat sukar. Hasil jadi tenunan ini akan membuat pola geometris rapi yang serasi dan sangat indah.

Kain/wastra gringsing dibuat oleh masyarakat desa Tenganan Pagringsingan di Karangasem. Akan tetapi, proses pencelupan warna dilakukan di daerah Nusa Penida. Proses penenunan dilakukan setelah benang-benang selesai diwarnai dan siap ditenun. Benang-benang tersebut ditenun dengan alat yang disebut cagcag, yaitu alat tenun tradisional menggunakan por, semacam busur yang disangkutkan pada pinggang penenun sebagai penahan rentangan benang lungsi. Alat ini akan menghasilkan kain berbentuk tabung. Setelah dipotong mengikuti alur pakan, kain tersebut akan menjadi persegi panjang berukuran lebar $30-100 \mathrm{~cm}$, panjang $125-200 \mathrm{~cm}$. Bagian pinggir dapat dibiarkan terurai, tetapi kadang ada juga yang dipotong rapi, sementara bagian tengah kain membentuk berbagai motif seperti motif wayang, motif cemplong, cempaka, sananempeg dan lain sebagainya. 


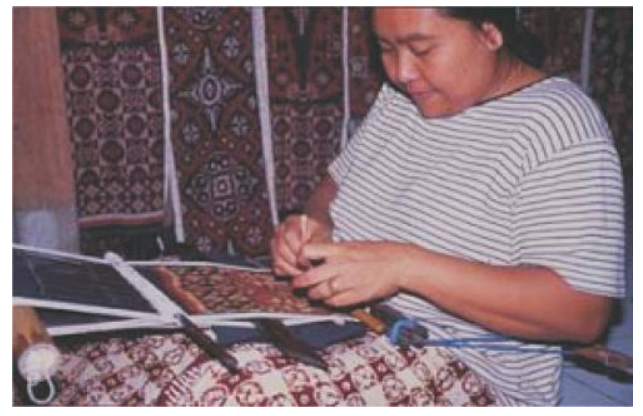

Gambar 1. Teknik menenun menggunakan alat tenun duduk (sumber foto: Koleksi pribadi, 2011)

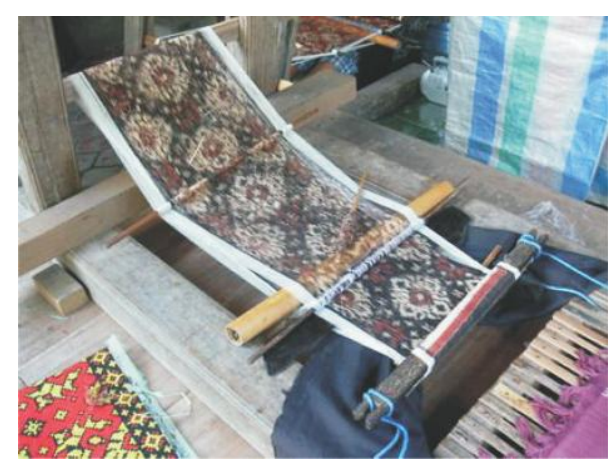

Gambar 2. Alat tenun cag-cag yang digunakan untuk menenun kain gringsing oleh masyarakat desa Tenganan Pagringsingan (Sumber foto: Koleksi pribadi, 2011)

Kain Bebali atau wastra Wali sangat berperan dalam berbagai upacara keagamaan di Bali. Hal ini karena kain bebali atau Wastra Wali sarat dengan nilainilai filosofi. Beberapa jenis kain diyakini memiliki kekuatan magis yang dipercaya mampu menyembuhkan berbagai macam penyakit. Penggunaan wastra wali atau kain bebali dalam pelaksanaan upacara adat atau yadnya merupakan tradisi turun temurun yang telah diatur dalam pustaka-pustaka suci atau lontar suci di Bali, seperti lontar Rare Angon, Ketatwan Ibu, Janma Khauripan, Ekaparama, lontar pitutur Sanghyang Jagat Natha, dan darma Kahuripan.

\section{Korelasi Motif, Teknik, Fungsi, dan Arti Simbolik Kain Geringsing}

Kain bebali berasal dari dua kata, yaitu kain dan bebali. Kain merupakan hasil tenunanyang berguna untuk menutupi tubuh. Sementara itu, bebali berarti upacara. Jadi kain bebali adalah suatu hasil tenunan yang dapat dipergunakan untuk kepentingan upacara. Sama halnya dengan Wastra Wali atau kain Bali, wastra berarti kain dan wali berarti upacara. Wastra Wali artinya kain yang berfungsi untuk upacara.

Pemakaian kain bebali atau wastra wali sebagai sarana budaya dan upacara keagamaan ditentukan oleh unsur dari masing-masing kain tersebut, seperti bahan yang gunakan, warna, ukuran, bentuk, dan motif yang ditampilkan. Kain bebali memiliki arti penting bagi masyarakat Bali karena memiliki nilai-nilai tertentu, seperti nilai guna,nilai artistik, nilai etika, dan nilai estetika, serta memiliki makna di dalam kehidupan socio cultural.

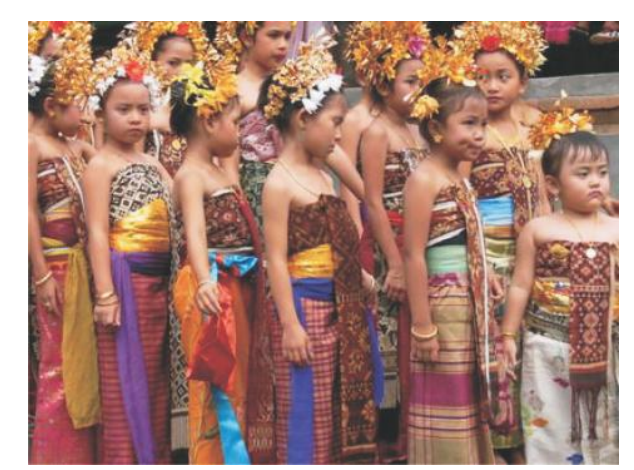

Gambar 3. Penari Rejang Dewa menggunakan kain gringsing pada upacara adat keagamaan di desa Tenganan Pagringsingan, Bali (Sumber foto: Nietz Photography, 2011)

Umat Hindu Bali tidak pernah lepas dari upacara-upacara keagamaan. Dalam pelaksanaan upacara-upacara tersebut, berbagai sarana dan prasarana digunakan sebagai pendukung dan pelengkap upacara maupun upakara. Salah satunya berupa kain yang memiliki sentuhan sakral dan mempunyai nilai penting dalam pelaksanaan upacara yang juga mempunyai nilai-nilai filsafat tinggi. Kain ini di samping digunakan untuk kepentingan upacara juga dapat digunakan sebagai sarana pengobatan.

Pada zaman dahulu kain bebali atau wastra wali dibuat oleh orang-orang yang sudah tua (orang yang sudah baki), sebab orang yang sudah baki (yang tidak mengalami menstruasi lagi dianggap bersih/suci). Sementara itu, orang yang sedang mengalami menstruasi dilarang menenun kain karena dianggap masih kotor. Hal ini dilakukan karena kain tersebut merupakan kain sakral yang digunakan untuk kepentingan upacara ritual keagamaan. Kain ini digunakan pada upacara-upacara ritual, seperti upacara mepetik (potong rambut), upacara mepandes (potong gigi), mesakapan (pernikahan), dan upacara merajah (menulis huruf-huruf tertentu pada bagian badan tertentu, tempat-tempat, atau benda-benda yang disakralkan). 
Dalam masyarakat Hindu Bali kain bebali atau wastra wali tidak jauh berbeda fungsinya dengan kain (pakaian), yaitu sebagai pelindung tubuh dari sengatan matahari, hujan, dingin, gangguan serangga, dan gangguan-gangguan yang lain. Fungsi dalam hal ini merupakan fungsi dalam pengertian umum, yang berlaku dalam ranah budaya. Fungsi tersebut berperan memberi manfaat atau nilai kegunaan bagi sesuatu, baik intrinsik maupun eksternsik. Seperti diungkapkan Koentjaraningrat (1987:165), fungsi tidak hanya sekedar hubungan biologis manusia, tetapi juga bersifat interaktif dalam arti mempunyai hubungan dengan alam yang berkaitan dengan kompleksitasnya.

Pendapat tersebut sesuai dengan fungsi kain bebali bagi masyarakat Hindu Bali. Selain sebagai pelindung tubuh, kain bebali atau wastra wali juga mempunyai fungsi etika. Ia digunkan untuk keperluan tertentu sesuai dengan peruntukannya, yang didasari atas aturan desa-kala-patra(tempat, waktu, dan keadaan). Sebagai contoh, kain gringsing memiliki fungsi sakral untuk kepentingan upacara agama adat dan fungsi profan terkait dengan sosial, ekonomi, dan kemasyarakatan yang selalu berubah. Sementara itu, sebagai karya seni ia memiliki fungsi estetis, yaitu suatu kualitas pada kain gringsing yang dapat memenuhi kebutuhan ekspresif.

Dilihat dari sudut pandang estetika, kain gringsing merupakan karya estetik yang bermakna sebagai sebuah simbol yang dipercaya memiliki daya, kekuatan,dan diyakini oleh masyarakat serta lingkungannya. Fungsi religi pada kain gringsing lebih kuat dibandingkan fungsi sebagai pelindung badan. Pada masa lampau, kebiasaan masyarakat Bali tidak menggunakan penutup dada,meskipun mereka juga memiliki baju tradisional kebaya. Jika ada upacara tertentu, barulah masyarakat berhias diri, kain kemben digunakan pada wanita bukan untuk menutup dada, tetapi untuk mengangkat dada agar terlihat indah.

Kain gringsing ditenun masyarakat Bali Aga salah satunya ditujukan untuk menolak penyakit. Kain gringsing berasal dari kata gering yang artinya sakit atau penyakit, sing artinya tidak ada. Jadi kain gringsing berfungsi untuk menolak penyakit dan desa Pagringsing adalah salah satu desa yang mempunyai kiat untuk menolak penyakit lewat kain gringsing tersebut. Bahkan konon ceritanya, ada kain gringsing yang diwarnai menggunakan darah manusia untuk menciptakan warna merah-hitam berkarat. Hal ini untuk menunjukkan pengorbanan dan diharapkan dapat menjadi tumbal untuk terbebas dari penyakit. Benar atau tidaknya cerita itu yang jelas, seperti pada umumnya, pewarnaan kain tradisional sebelum masa industrialisasi dapat dihasilkan dari bahan alam, misalnya warna merah yang didapat dari akar mengkudu. Sementara hitam didapat dengan merendam kain dalam minyak kemiri yang dicampur dengan abu kayu dan alkali.

Kain gringsing sebagai hasil karya seni yang memiliki ciri khas dan fungsi yang sangat sinkron dengan karya-karya seni pada zaman prasejarah ini memiliki sifat magis dan religius, karena tujuan pembuatannya adalah untuk mendapatkan kekuatan-kekuatan yang dapat mempertahankan hidup. Bentuk dan motifnya yang sederhana dengan menggunakan pewarnaan alami, seperti darah binatang, getah pohon, kulit kayu, daun-daunan merupakan salah ciri dari karya seni jaman pra sejarah.

Pada umumnya, kain gringsing memiliki tiga warna dasar, yaitu putih (atau putih tulang) yang menggambarkan angin, hitam yang menggambarkan air, dan merah yang menggambarkan api. Sesuai dengan penggambaran karakter dewa Brahma, Wisnu, dan Siwa. Pada masyarakat Hindu Bali tiga warna tersebut disebut juga sebagai warna tridatu. Warna tridatu dianggap sebagai warna sakral karena merupakan simbol dari dewa Brahma, Wisnu, dan Siwa, sehingga dalam setiap upacara ritual selalu digunakan untuk warna berbagai media, seperti kain poleng merah-putih-hitam atau benang tridatu. Kain gringsing juga dikenal dalam dua pembagian warna, yaitu Gringsing Selem (Gringsing Hitam) dan Gringsing Barak (Gringsing Merah).

Adapun motif-motif kuno kain gringsing yang dikenal, meliputi 1) Wayang kebo, 2) Cemplong, 3) Cecempakan, 4) Lubeng, 5) Teteledan, 6) Batung Tuhung, 7) Patlikur Isi, 8) Patlikur, 9) Enjekan Siap, 10) Wayang Putri, 11) Pitri Dedari, 12) Lubeng luhur, 13) geringsing kebo, 14) Pepare, 15) Gegonggangan, 16) Sanan Empeg, 17) Sitan Pegat, 18) Dinding Ai, 19) Dinding Sigading, 20) Talidandan, 21) enjekan siap, dan 22) Wayang. Sampai saat ini, masih ada beberapa kain gringsing yang tidak diketahui namanya. Berikut ini adalah contoh beberapa jenis dan motif kain gringsing dengan berbagai fungsinya.

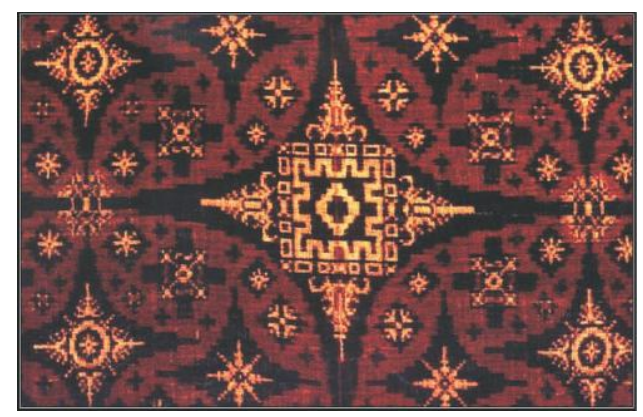

Gambar 4. Kain Gringsing motif Lubeng luhur (Sumber foto: dokumentasi pribadi, 2011)

Gambar di atas disebut Kain Gringsing Lubeng Luhur, kain ini berukuran $177 \mathrm{~cm} \times 167 \mathrm{~cm}$ (tergolong kain gringsing petangdasa luhur) dengan motif terdiri dari bentuk telupuh, celedu (kalajengking), cakra, bebintangan (bintang),dan batun celagi (biji buah asam). Kain ini berfungsi sebagai busana adat pada upacara 
menek kelih (menginjak dewasa), pengangge pelinggih (penutup bangunan suci), upacara nuur titra (memohon air suci) ke Gunung Agung. Kain ini banyak digunakan oleh masyarakat Bali, terutama di desa Tenganan, Pegringsingan.

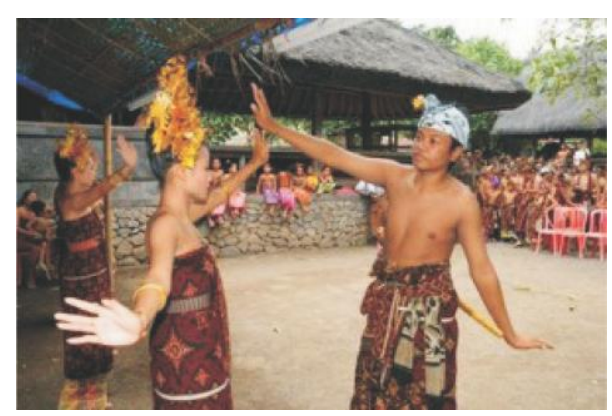

Gambar 5. Penggunaan Kain Gringsing Lubeng Luhur pada Upacara Menek Kelih (menginjak dewasa) (Sumber foto: dokumentasi pribadi, 2011)

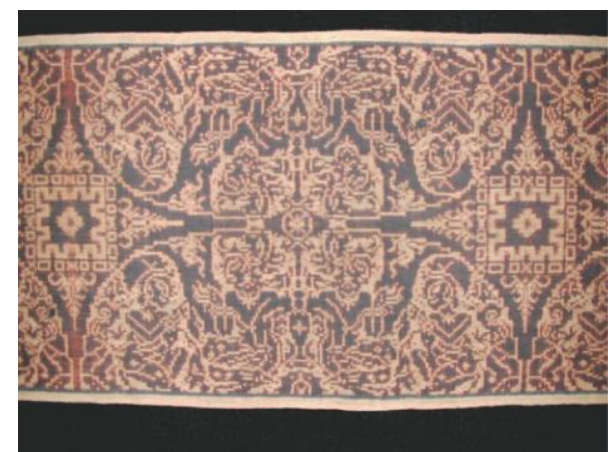

Gambar 6. Kain Gringsing Kebo (Sumber foto: Koleksi pribadi, 2011)

Kain Gringsing Kebo, seperti gambar di atas, berukuran $188 \mathrm{~cm}$ x $58 \mathrm{~cm}$. Ragam hias atau motif jenis kain gringsing ini berupa prembon, yaitu terdiri dari tiga atau lebih motif-motif gringsing, seperti bentuk wayang, bentuk teledu (kalajengking), gigi barong, panggal asu, pelupuh, tumpal, dan motif-motif geometris. Ciri khas dari jenis kain ini adalah terdapat empat motif buah keledu (kalajengking) yang ditampilkan dengan bentuk kaki-kakinya yang saling berhubungan dan dibatasi dengan motif tapak dara. Kain ini berfungsi sebagai sarana upacara, sebagai wastra penutup pelinggih (bangunan suci), sebagai busana penari rejang, sebagai busana untuk upacara potong gigi (mepandes/mesangih), sebagai busana pengantin gaya Tenganan Pegringsingan.

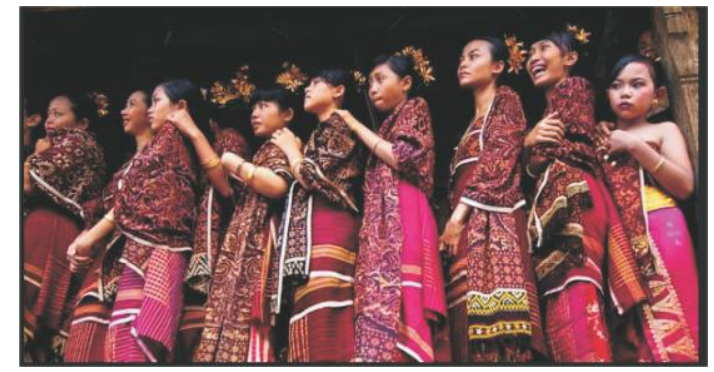

Gambar 7. Kain Gringsing Kebo Digunakan oleh Penari Rejang pada Upacara Ritual Keagamaan di Daerah Tenganan Pegringsingan, Bal (Sumber foto: Nietz Photography, 2011)

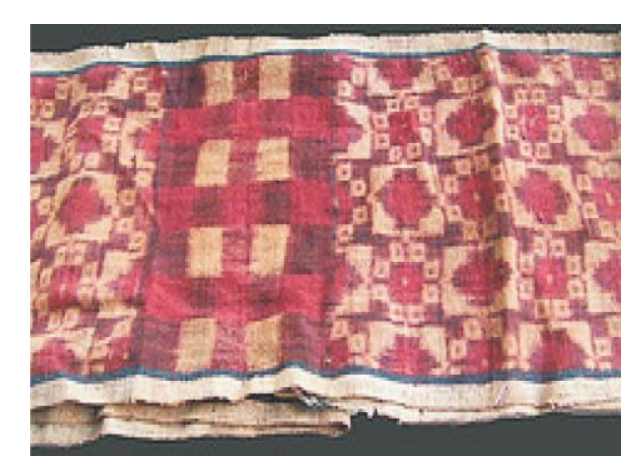

Gambar 8. Kain Gringsing Sanan Empeg (Sumber Foto: Nietz Photography, 2011)

Kain gringsing jenis sanan empeg berukuran $184 \mathrm{~cm}$ x $19 \mathrm{~cm}$ dengan ragam hias atau motif berupa pinggiran/pepuluh, bebintangantampak dara, sigading poleng, dan kombinasi motif yang lain. Fungsi utama dari kain ini adalah sebagai sabuk atau sabuk tubuan (cawet), sedangkan fungsi khususnya adalah digunakan untuk upacara manusa yadnya penolak bala, mebayuh oton (ruwatan). Upacara mebayuh oton (ruwatan) ini dilakukan apabila terdapat tiga bersaudara, kakak dan adiknya meninggal, maka yang masih hidup harus diruwat atau dibayuh. Menurut kepercayaan masyarakat Bali, terutama masyarakat desa Tenganan Pegringsingan, orang yang memakai kain gringsing jenis ini dipercaya dapat terhindar dari penyakit dan lebih kompleks lagi gringsing adalah penolak mara bahaya.

Seperti pendapat Van Gennep, seorang ahli folklore Perancis, dalam bukunya tentang asas-asas ritus dan upacara, Rites de Passage (1873-1957), menyatakan bahwa ritus dan upacara religi secara universal pada asasnya berfungsi sebagai aktivitas untuk menimbulkan kembali semangat kehidupan sosial antara warga masyarakat (Koentjaraningrat, 2007:74). 
Berbagai analisis terhadap masalah asas dan asal mula religi yang dikembangkan oleh berbagai ahli, masing-masing dilakukan dengan metode berbeda, seperti analisa Soderblom yang berusaha menggabungkan semua pendekatan sehingga memberi pelajaran bahwa gejala religi merupakan gejala yang sangat kompleks. Menurut Koentjaraningrat, konsep religi dipecah ke dalam lima komponen yang mempunyai perannya sendiri-sendiri, tetapi sebagai bagian dari suatu sistem yang berkaitan erat satu sama lain.Kelima komponen itu adalah 1) emosi,keagamaan, 2) sistem keyakinan, 3) sistem ritus dan upacara, 4) peralatan ritus dan upacara, dan 5) umat agama. (Koentrjaraningrat, 2007:80).

Sesuai dengan kelima komponen tersebut sangat jelas bahwa keberadaan kain bebali merupakan sarana ritus dan upacara. Ia merupakan komponen yang sangat penting dalam aktivitas religi masyarakat Bali. Dari beberapa contoh di atas, sangat jelas bahwa kain gringsing memiliki fungsi yang sangat penting, selain sebagai pakaian atau pelindung tubuhjuga merupakan bagian dari sarana dan prasarana ritual keagamaan dari kepercayaan masyarakat pendukungnya.

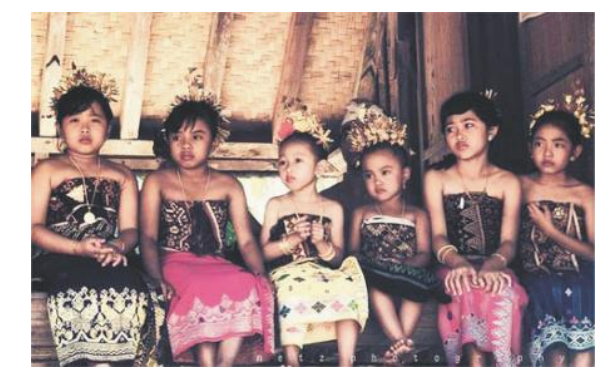

Gambar 9. Penggunaan Kain Gringsing dan Kain Songket oleh Anak-anak di Desa Tenganan Pagringsingan pada Upacara Adat (Sumber foto: Netz photograpy, 2011)

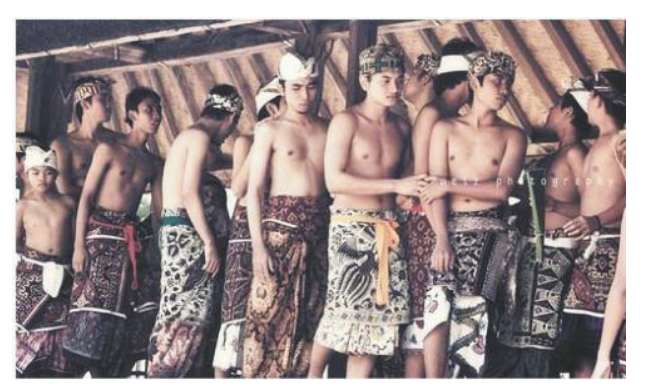

Gambar 10. Kain Geringsing digunakan oleh Teruna Desa (Pemuda Desa) pada Upacara Ritual Perang Pandan di Desa Tenganan Pegringsingan (Sumber foto: Netz Photograpy, 2011)

\section{KESIMPULAN}

Kain Gringsing sebagai kain bebali atau wastrawali merupakan hasil budaya masyarakat Bali. Dalam sistem sosial budaya masyarakat tradisional, kain gringsing memiliki keterkaitan sangat erat dengan berbagai aktivitas maupun upacara adat. Keberadaan wastrawali atau kain bebali mengandung nilai-nilai sosial, nilai-nilai simbolis, nilai-nilai estetika, serta pesan-pesan moral yang disajikan melalui bentuk-bentuk simbol, sehingga dapat dijadikan tuntunan, tatanan, dan tontonan bagi masyarakat pendukungnya.

Sebagai hasil seni atau benda budaya, kain gringsing memiliki jiwa yang halus, indah, luwes, magis, dan penuh toleransi, serta fleksibel. Keberadaannya bukan saja digunakan sebagai bahan pakaian dan sarana upacara, tetapi juga telah berkembang mengikuti perkembangan zaman sebagai benda-benda seni yang multiguna dan bentuk ekspresi dari masyarakat pendukungnya. Dalam dunia seni, kain bebali memiliki nilai-nilai klasik yang mampu memberikan ilham bagi lahirnya gaya seni dekorasi, modern art,serta karya seni dan kerajinan-kerajinan lainnya, yang tumbuh dan berkembang di lingkungan yang sama. Karya-karya yang terinspirasi oleh keberadaan kain bebali tersebut, antara lain kerajinan anyaman bambu dan ukiran kayu.

\section{DAFTAR PUSTAKA}

Sachari, Agus. 2006. Estetika Makna Simbol dan Daya. Bandung: Penerbit ITB Hadi, Y Sumandyo.2006. Seni dalam Ritual Agama, Yogyakarta: Pustaka

Ihromi. T.O. 2006. Pokok-pokok Antropologi Budaya.Jakarta: PT Gramedia Kuntjaraningrat. 2007. Sejarah Teori Antropologi. Jakarta: UI Press

Kartiwa, Suwati. 2007.Tenun Ikat Ragam Kain Tradisional Indonesia. Jakarta: PT Gramedia

Wiana, I Ketut, 2000. Arti dan fungsi sarana persembahyangan: Surabaya: Paramita 
